\title{
PROCESSING EDWARD STEICHEN'S CELEBRITY PORTRAIT PHOTOGRAPHS AT GEORGE EASTMAN HOUSE
}

\author{
By \\ Meghan Shaw \\ BFA, University of Colorado at Denver, 2005
}

An applied thesis project

presented to Ryerson University and George Eastman House
in partial fulfillment of the requirements for the degree of Master of Arts in the program of

Photographic Preservation and Collections Management

Toronto, Ontario, Canada, 2013

(C) Meghan Shaw 2013 


\section{Authors Declaration for an Electronic Submission of a Thesis}

I hereby declare that I am the sole author of this thesis. This is a true copy of the thesis, including any required final revisions, as accepted by my examiners.

I authorize Ryerson University to lend this thesis to other institutions or individuals for the purpose of scholarly research.

I further authorize Ryerson University to reproduce this thesis by photocopying or by other means, in total or in part, at the request of other institutions or individuals for the purpose of scholarly research.

I understand that my thesis may be made electronically available to the public. 


\begin{abstract}
Processing Edward Steichen's Celebrity Portrait Photographs at George Eastman House Master of Arts, 2013

Meghan L. Shaw

Photographic Preservation and Collections Management

Ryerson University and George Eastman House

This thesis is an applied project undertaken to process celebrity portraits by Edward Steichen that were gifted to George Eastman House by Steichen's widow, Joanna Steichen, in 2002. These photographs were made for Condé Nast Publications between 1923 and 1937. This thesis discusses processing donations of photographic materials, identifying acetate and nitrate negatives, handling gelatin silver contact prints, and rehousing procedures based on institutionalspecific collections management policies. The analytical paper portion discusses processing methods, proposes future processing procedures, and addresses the relationship between the contact prints and printed images in Vanity Fair magazine in order to highlight the importance of creating relationships between objects in museum collections.
\end{abstract}




\section{Acknowledgements}

This thesis is dedicated to the many people who have supported me in my passions and endeavors. I would like to express gratitude to the following:

George Eastman House, for entrusting me to handle and research an important piece of photographic history.

Joe Struble and Selina Lamberti, for their patience with my questions and allowing me to access the materials day after day, during my study at George Eastman House.

Barbara Puorro Galasso, for taking the time to document my processing method and allowing me to work alongside her to handle the prints and negatives, both to discuss and research with her, and to use as illustrations within this thesis.

Jamie M. Allen, my thesis advisor, for her patient direction, organization, and encouragement in between the numerous demands on her as an Assistant Curator of Photographs.

Roger Bruce, my second reader, for his time and critique of this document.

I would like to express gratitude to my parents, Rob and Kathy Shaw, who deserve thanks that cannot justly be expressed here. 


\section{Table of Contents}

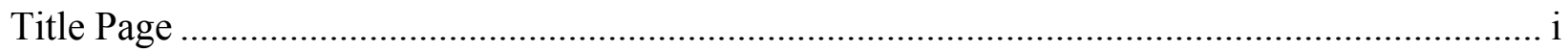

Authors Declaration for an Electronic Submission of a Thesis ............................................... ii

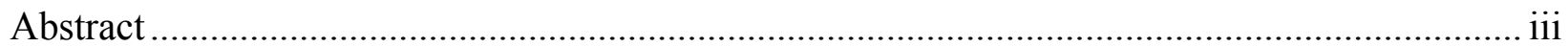

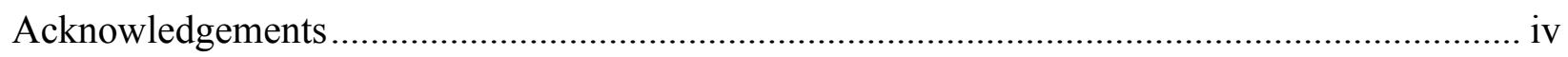

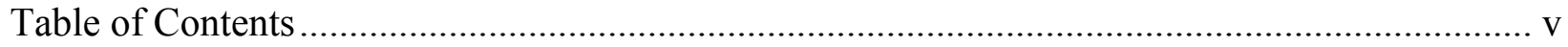

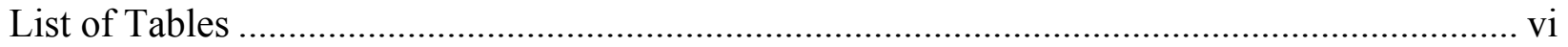

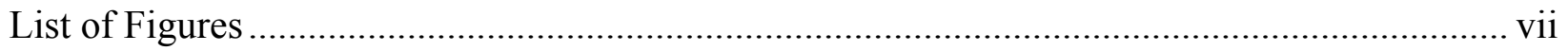

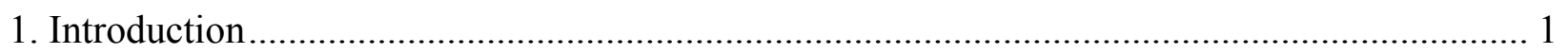

2. Literature Survey ….................................................................................................... 5

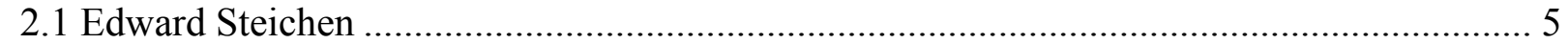

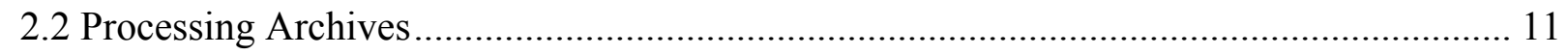

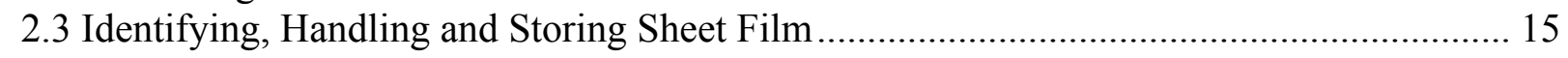

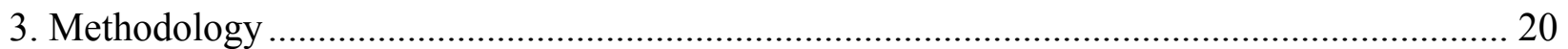

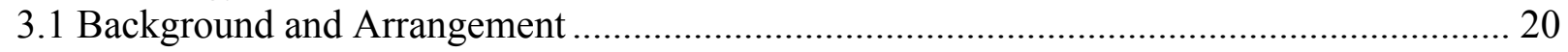

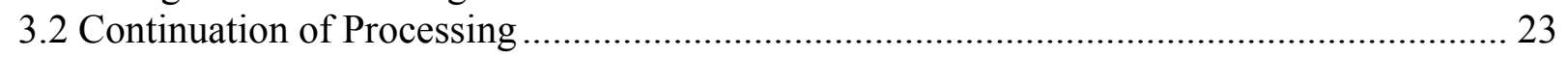

4. Identifying matches to Vanity Fair Library Material and Other Publications ...................... 31

5. Recommendations for Continued Work/Conclusions ...................................................... 35

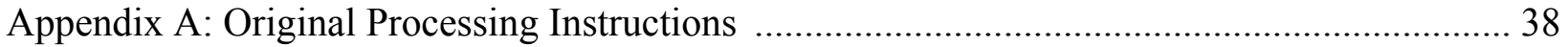

Appendix B: Modified Processing Instructions ................................................................ 40

Appendix C: Sample from "Negatives Box Inventory" ...................................................... 42

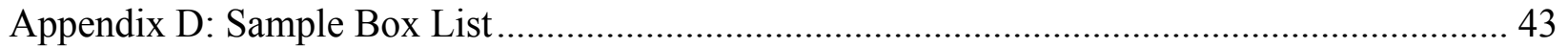

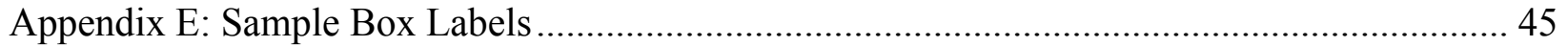

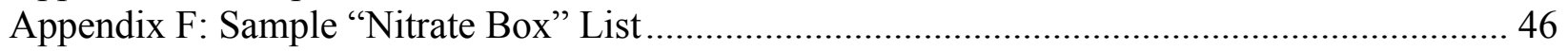

Appendix G: Sample from "Nitrate Materials Removed" List ............................................. 47

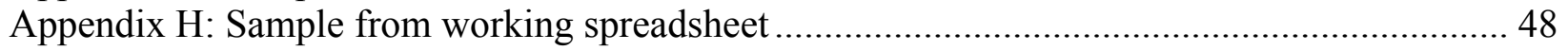

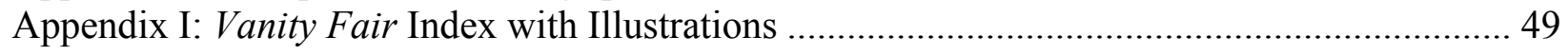

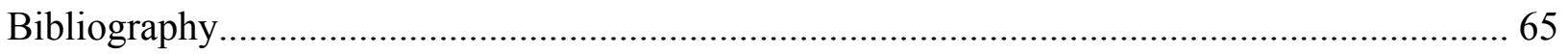




\section{List of Tables}

Table 1: Detail of spreadsheet: Object Counts...................................................................... 24

Table 2: Detail of spreadsheet: Descriptions ..................................................................... 24

Table 3: Detail of spreadsheet: Notch Codes ...................................................................... 25

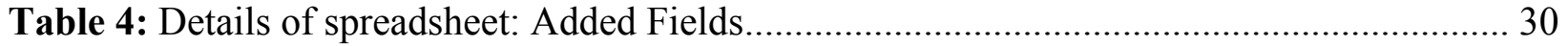

Table 5: Sample from Working Spreadsheet (Appendix H) ............................................... 48 


\section{List of Figures}

All photographs (C)orge Eastman House collection. Illustrations are reproduced without retouching or color corrections. Contact prints are shown with the folder on which they are adhered. The following are descriptive titles based on the inscriptions found on the original file folders. Images of the processing method are courtesy of Barbara Puorro Galasso, Photographer, George Eastman House.

Figure 1: Edward Steichen, Self-Portrait, undated. Negative and contact print, 2001:3546:0001 and 2001:3547:0001.

Figure 2: Bankers box of unprocessed celebrity material............................................... 21

Figure 3: File folders with original handwritten inscriptions ............................................. 21

Figure 4: Detail of contact print adhered to original envelope ........................................... 24

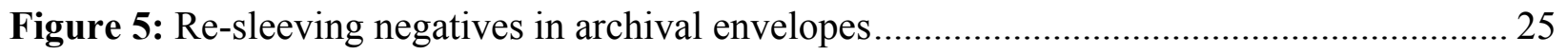

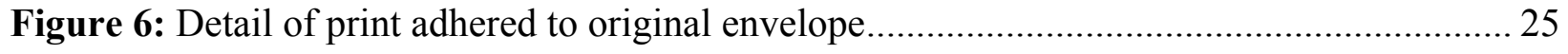

Figure 7: Assigning an accession number to a contact print ............................................. 26

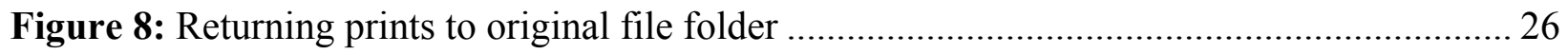

Figure 9: Edward Steichen, Lady Diana Manners as Madonna in "The Miracle," with sculpture and the sculptor Joe Davidson, 1924. Nitrate negative with transmitted light and raking

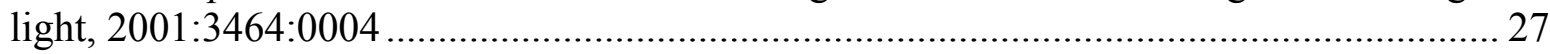

Figure 10: Edward Steichen, June McCloy, 1931. Nitrate negative and contact print,

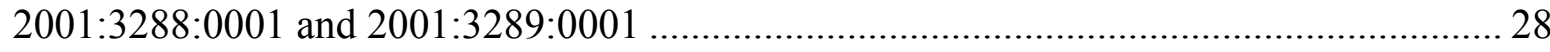

Figure 11: Detail of 2001:3288:0001 negative deterioration................................................ 28

Figure 12: (Left) Edward Steichen, Victor Moore as Alexander Throttlebottom in "Of Thee I Sing,” 1933. Contact print, 2001:3361:0001. (Right) Vanity Fair, November 1933, Page 42. Richard and Ronay Menschel Library, George Eastman House Collection........................ 32

Figure 13: Edward Steichen, Victor Moore as Alexander Throttlebottom in "Of Thee I Sing," 1933. Negative, 2001:3360:0001, 2001:3360:0002, and 2001:3360:0003.

Figure 14: Vanity Fair, April 1933. Page 28 and 29. Richard and Ronay Menschel Library, George Eastman House Collection

Figure 15: Edward Steichen, Harold Nicholson, January 6, 1933. Negative and contact print, 2001:3388:0001 and 2001:3389:0001 
Figure 16: Edward Steichen, Sir Arthur Salter, November 16, 1932. Negative and contact print, 2001:3492:0004 and 2001:3393:0004 50

Figure 17: Vanity Fair, July 1933, Page 23. Richard and Ronay Menschel Library, George Eastman House Collection 51

Figure 18: Edward Steichen, Ruth Bryan Owen, May 8, 1933. Negative and contact print, 2001:3414:0001 and 2001:3415:0001

Figure 19: Vanity Fair, July 1933, Page 30. Richard and Ronay Menschel Library, George Eastman House Collection 52

Figure 20: Edward Steichen, Lily Pons, January 6, 1932. Negative, 2001:3454:0001 52

Figure 21: Vanity Fair, July 1933, Page 44. Richard and Ronay Menschel Library, George Eastman House Collection 53

Figure 22: Edward Steichen, Aline McMahon, 1933. Negative and contact print, 2001:3294:0001 and 2001:3295:0001 53

Figure 23: Vanity Fair, September 1933, Page 17. Richard and Ronay Menschel Library, George Eastman House Collection

Figure 24: Edward Steichen, George Nelson Peek, May 27, 1933. Negative and contact print, 2001:3432:0001 and 2001:3433:0001

Figure 25: Vanity Fair, November 1933, Page 19. Richard and Ronay Menschel Library, George Eastman House Collection

Figure 26: Edward Steichen, Raymond Moley, May 24, 1933. Negative and contact print, 2001:3340:0001 and 2001:3341:0001 55

Figure 27: Vanity Fair, November 1933, Page 42. Richard and Ronay Menschel Library, George Eastman House Collection 56

Figure 28: Edward Steichen, Victor Moore as Alexander Throttlebottom in "Of Thee I Sing," 1933. Negative and contact print, 2001:3360:0001 and 2001:3361:0001.... 56

Figure 29: Vanity Fair, November 1933, Page 46. Richard and Ronay Menschel Library, George Eastman House Collection

Figure 30: Edward Steichen, Norma Shearer, July 25, 1933. Negative and contact print, 2001:3316:0003 and 2001:3317:0003 
Figure 31: Vanity Fair, June 1934, Page 52. Richard and Ronay Menschel Library, George Eastman House Collection

Figure 32: Edward Steichen, Lupe Velez, August 15, 1932. Negative and contact print, 2001:3652:0003 and 2001:3653:0003 .....

Figure 33: Vanity Fair, June 1934. Page 60. Richard and Ronay Menschel Library, George Eastman House Collection....

Figure 34: Edward Steichen, Eleanor Holm, July 14, 1932. Negative and contact print, 2001:3396:0011 and 2001:3397:0011 60

Figure 35: Vanity Fair, August 1934. Page 52 and 53. Richard and Ronay Menschel Library, George Eastman House Collection

Figure 36: Edward Steichen, Self-Portrait. Negative and contact print, 2001:3554:0016 and 2001:3555:0015

Figure 37: Vanity Fair, February 1935, Page 20. Richard and Ronay Menschel Library, George Eastman House Collection.

Figure 38: Edward Steichen, Gladys Swarthout as Stephano in "Romeo and Juliet" at the Metropolitan Opera, 1934. Red filter negative and contact print, 2001:3594:0001 and 2001:3595:0001

Figure 39: Edward Steichen, Gladys Swarthout as Stephano in "Romeo and Juliet" at the Metropolitan Opera, 1934. Blue filter negative and contact print, 2001:3594:0002 and 2001:3595:0002

Figure 40: Vanity Fair, April 1935, Page 21. Richard and Ronay Menschel Library, George Eastman House Collection

Figure 41: Edward Steichen, Philip Merivale as General George Washington in "Valley Forge," 1935. Negative and contact print, 2001:3310:0001 and 2001:3311:0001

Figure 42: The Delineator, October 1933, Page 23

Figure 43: Edward Steichen, Lady (Marchioness) Milford Haven, 1931, Negative and contact print, 2001:3452:0002 and 2001:3453:0002 64 



\section{Introduction}

Edward Steichen's extensive and wide-ranging career as a photographer spans decades and movements within photography, but also within art and contemporary culture. Steichen's career varied throughout his life, as he experimented with many forms of photography rather than holding to one type of image making. Before he began his career at Condé Nast Publications in 1923, he was a member of the Camera Club of New York, making Pictorialist images and working alongside Alfred Stieglitz. Stieglitz published many of Steichen's images in Camera Work (for which Steichen designed the logo). Steichen also helped to establish and exhibit photographs at the Little Galleries of the Photo-Secession, also known as 291, located in New York City. Eventually Steichen's photographic interests shifted from Pictorialism to photojournalism. As a result, he severed ties with Stieglitz in 1915. In 1917 Steichen joined the Signal Corps, but was transferred to the US Army Expeditionary Forces Air Service and made commander of the photographic division. ${ }^{1}$

Following a respite in France after World War I, Steichen returned to New York to "make a living." Upon his return in early 1923, he happened upon an issue of Vanity Fair magazine, within which he found a photograph of himself captioned, "the greatest living portrait photographer."3 The image was part of an article written by Frank Crowningshield, a journalist, art critic, and the current editor of Vanity Fair. The article went on to note that Steichen had given up photography for painting. Steichen later spoke of this article, indicating that he had written a letter to Crowningshield to correct the announcement, noting, "[his] information service was faulty, for I had not given up photography. On the contrary, I had given up painting and

\footnotetext{
${ }^{1}$ Grace M. Mayer, "Biographical Outline," in Steichen the Photographer (New York: MoMA, 1961), 69.

${ }^{2}$ Penelope Niven, Steichen: A Biography (New York: Clarkson Potter Publishers, 2004), 498.

${ }^{3}$ Edward Steichen, A Life in Photography (London: W.H. Allen, 1963), chapter 7, n.p.
} 
decided to devote myself to photography." "4 This letter prompted a swift response from Crowningshield, who asked Steichen to have lunch with Mr. Condé Nast and himself. Speaking of this meeting, Steichen noted that they "proposed that I work for Condé Nast Publications as chief photographer," a position he began immediately. ${ }^{5}$ By the time his career culminated in 1937, he had taken thousands of photographs of well-known and famous personalities of the era. These "celebrity" portraits were chiefly created for Vanity Fair and Vogue and many of the images appeared within the pages of those magazines.

In January of 2002, Joanna

Taub Steichen, Edward Steichen's

widow and the beneficiary of his

estate, loaned a large quantity of

his photographs to George

Eastman House. This collection of materials consisted of
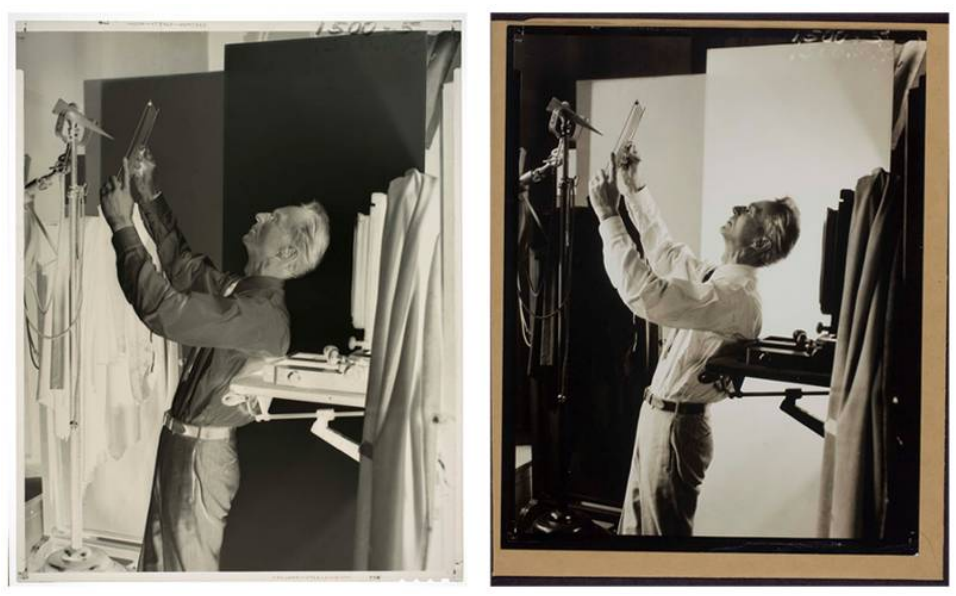

Figure 1

"photographs, negatives, contact sheets, color slides,

autochromes, various archival materials and memorabilia

Edward Steichen Self-Portrait, Undated. Negative and contact print 2001:3546:0001 2001:3547:0001

pertaining to the photographer, curator and writer Edward

Steichen."6 According to unpublished notes in the 2000 appraisal of these materials, "as Joanna T. Steichen has described, Steichen decided to edit his life's work in 1960 and 1961 by discarding negatives that he felt were unworthy of preservation." ${ }^{77}$ The materials that remained

\footnotetext{
${ }^{4}$ Ibid.

5 Ibid.

${ }^{6}$ Penelope Dixon, "Section V. Description of Work" in An Appraisal of Photographic Materials by Edward Steichen Provided for Joanna Steichen, Penelope Dixon \& Associates, Inc., October 15, 2000. Reprinted with permission from The Estate of Edward Steichen.

${ }^{7}$ Ibid., 8-9. Reprinted with permission from The Estate of Edward Steichen.
} 
are the contents of this collection. Included among the material is a selection of celebrity portraits made during Steichen's years at Condé Nast. At the time of Mrs. Steichen's 2002 donation, and throughout the following few years, these materials were partially inventoried and rehoused by staff and students under supervision of the Collection Management Department. Upon Mrs. Steichen's death in 2010, this collection became property of the museum by way of her bequest. ${ }^{8}$

For my applied thesis, I continued to process the celebrity related objects from this gift by adapting the methods put into place since their arrival at Eastman House in 2002. This work has achieved two main objectives: improving their storage condition, and developing the inventory of objects to provide access for future study. The project included rehousing negatives, identifying and separating nitrate materials, and establishing connections between the celebrity photographs and thirteen issues of Vanity Fair magazine held in the Richard and Ronay Menschel Library at Eastman House.

This analytical paper discusses the decisions I made during the applied project, including changes to the original processing methods. It outlines the steps I took when processing the negatives and contact prints, and discusses a plan to continue and complete processing of the material in the donation. My recommendations, which are discussed at the end of this thesis, include applying my methodology to the remaining materials in the 2002 donation; cataloguing the celebrity negatives and contact prints; and rehousing the remaining prints. Additionally, I have created a model to continue matching celebrity portrait negatives and contact prints to printed versions that appear within issues of Vanity Fair magazine. In addition to the main objectives, this applied project expanded the understanding of Edward Steichen's work held in

\footnotetext{
${ }^{8}$ Joanna Steichen, "Receipt, Release, Refunding and Indemnification Agreement" File No.2010-2660 (State of New York, New York County, Surrogate's Court: 2010), 1. Reprinted with permission from The Estate of Edward Steichen.
} 
the Eastman House collections. Additionally, it has increased the understanding of Edward Steichen as a portrait photographer during his years at Condé Nast Publications, as well as his reputation as a photographer of the elite and famous. 


\section{Literature Survey}

The literature survey that follows has been adapted to the methodology of this practical project. Research has been conducted based on three main categories: Edward Steichen at Condé Nast; processing collections material in archives; and identification, handling, and storage of acetate and nitrate film.

\subsection{Edward Steichen}

In processing the collection of celebrity portrait negatives and contact prints held at Eastman House, an examination of literature related to Edward Steichen was an essential part of research. In order to understand Edward Steichen's time at Condé Nast (between 1923 and 1937), it was necessary to research the trajectory of his career up to and throughout this time. This section addresses information on Steichen's Condé Nast years through biographical literature; Vanity Fair and Vogue articles; exhibition-related catalogues; and, finally, biographical timelines.

Biographies written about Steichen were the most logical place to start. Penelope Niven's Steichen: A Biography traces the evolution of his photographic pursuits beginning with his time as a painter, to his position as Curator of Photography at The Museum of Modern Art, and concludes with the end of his life. ${ }^{9}$ Niven states that his decision to stay with photography after spending time painting in France at the end of World War I was a decision made out of financial necessity as opposed to artistic pursuit. Regarding this transition, she states, "Steichen concluded that photography would be the surest way of earning the income he needed...New York would surely offer more opportunity for him than postwar Paris."10 This explanation of his relocation

\footnotetext{
${ }^{9}$ Penelope Niven, Steichen: A Biography (New York: Clarkson Potter Publishers, 2004).

${ }^{10}$ Ibid., 498.
} 
changes the understanding of his career path. Instead of remaining in France, he chose to return to New York for the prospect of work. Additionally, Niven references Steichen's autobiographical publication for its first-person accuracy and story-telling quality. This autobiography, A Life in Photography, offers a considerable amount of insight into his career through the use of anecdotes, letters, and photographs. ${ }^{11}$ In the chapter, "The Theater: Photographing the Reality Behind the Make-Believe," he writes,

Vanity Fair began a long procession of portraits of the great, the near-great and the would-be great. It didn't matter whether the sitter was a statesman, a writer, a poet, an actor, a prizefighter, or a musician. They were all interesting. The exciting thing was the variety in this procession that came to my studio to appear on the pages of Vanity Fair. ${ }^{12}$

This short account details the interest Steichen took in his subjects, showing that he understood the value his portraits had in the present and would come to have in the future. He goes on to write about his favorite portrait sittings and how he engaged with celebrated personalities such as Gloria Swanson, Charlie Chaplin, and Marlene Dietrich. These stories expand the understanding of his photographs, specifically his skills in easing the anxiety of his sitters and creating exceptional portraits as a result.

Similarly, Joanna Steichen's seminal work, Steichen's Legacy: Photographs, 1895-1973, expands the understanding of his career through personal narrative. ${ }^{13}$ In a chapter titled "Early Color Processes," she states, "while most of Steichen's work for magazines and advertising was published in black and white, I have boxes and boxes of three-color plates, red, yellow and blue, made for magazine publication in the 1920s and 30s. [After closing his studio] he brought his lab man, Noel Deeks, to Connecticut to set

\footnotetext{
${ }^{11}$ Edward Steichen, A Life in Photography (London: W.H. Allen, 1963).

${ }^{12}$ Edward Steichen, $A$ Life, Chapter 7, n.p.

${ }^{13}$ Joanna Steichen, Steichen's Legacy: Photographs, 1895-1973 (New York: Alfred A. Knopf, 2000).
} 
up the lab at Umpawaug and continue experimenting with color printing." ${ }^{.14}$ This statement is relevant to the material in the 2002 donation, because both two and threecolor separation negatives are present among the celebrity negatives. Albeit in very small quantities compared to the vast number of black and white negatives. For instance, a portrait of the actress Gladys Swarthout, that appears as a color reproduction in Vanity Fair $^{15}$ (see Appendix I) is one of the pairs of two-color separation negatives to which Joanna refers, now at Eastman House. The presence of color separation negatives shows Steichen's awareness of the technical changes within photography during his time at Condé Nast, and shows that Steichen was experimenting with, and made use of color technology in his portrait work.

Articles published within Vanity Fair and Vogue, including Clare Booth Brokaw's "Edward Steichen, Photographer" and Margaret Case-Harriman's "Steichen" were referenced for information on his personality and to gain an understanding of his working methods. ${ }^{16}$ In particular, Case-Harriman's tribute to Steichen paints a vivid picture and makes a fitting tribute.

She states,

I can see him now as he used to stand then, in the light from a big studio window, posing the actors, actresses, authors, bull fighters and other unpredictable celebrities whose pictures, by Steichen, later appeared in Vogue and Vanity Fair. He moved around them swiftly, sometimes squatting on his hands and knees to get a camera angle, sometimes appearing to forget all about taking pictures if his subject turned out to be self-conscious. ${ }^{17}$

\footnotetext{
${ }^{14}$ Ibid., 169.

${ }^{15}$ Vanity Fair, February 1935, 20.

${ }^{16}$ Clare Booth Brokaw, "Edward Steichen, Photographer," Vanity Fair, June 1932; Margaret Case-Harriman, "Steichen," Vogue, January 1938.

${ }^{17}$ Margaret Case-Harriman, "Steichen,” Vogue, January 1938, 38.
} 
This statement helps to identify the personality of Steichen as a successful portrait photographer who could engage with his subjects in a perceptive and considerate manner, and collaborate to produce a successful final result.

Retrospective exhibitions of Steichen's work have appeared at numerous large museums, and exhibition catalogues proved to be helpful surveys of his career. However, most exhibitions of Steichen's work span decades, themes, and movements in photography, and thus do not focus on specific genres such as his celebrity portraits, nor specific characteristics of them. However, some exhibition catalogue essays, such as Barbara Haskell's introductory essay in The Whitney Museum's catalogue for the 2000-2001 exhibition, "Edward Steichen," addresses one of the major themes found in his work; that of intentional and dramatic use of light. ${ }^{18}$ This theme can be traced back to his experimentation with controlled lighting scenarios in studio environments, such as those of his Condé Nast portraits. Haskell identifies a few of these techniques, such as "throwing multiple shadows of a single figure against a monochromatic background, dividing backgrounds into horizontal or vertical rectangles of light and dark, and montaging multiple images of one or more figures." 19 These techniques are evident in many of Steichen's celebrity photographs beginning in the 1920s and evolving into the 1930s. Haskell's essay is an example of one of the many exhibition catalogues related to the work of Steichen, in that it addresses major themes throughout his career.

Perhaps the most extensive of the exhibition catalogues on Steichen's work related to his commercial portraiture during the 1920s and 1930s is Todd Brandow and William A. Ewing's Edward Steichen: In High Fashion, the Condé Nast Years, 1923-1937, a "companion volume to the exhibition catalogue, Edward Steichen: Lives in Photography, published in

\footnotetext{
${ }^{18}$ Barbara Haskell, Edward Steichen (New York: Whitney Museum of Modern Art, 2000).

${ }^{19}$ Ibid., 32.
} 
2007. ${ }^{20}$ The book includes multiple essays and a preface by Ewing, Director of the Musée de l'Elysée, in which he states, "no other portrait photographer could rival Steichen for the volume of vivid, engaging studies he made of artists, athletes, actors, musician, writers, and statesmen for Vanity Fair. ${ }^{21}$ The many commercial, fashion and portrait photographs that appear throughout the publication support this statement. Ewing also writes an essay that opens the book, titled, “A Perfect Conjunction," in which he describes Steichen's evolution from Pictorialist, to war photographer to photojournalist, and the good fortune of large-scale publications to have a visionary such as him enter the world of commercial image making. ${ }^{22}$ Ewing states, "Steichen was a picture maker, not a picture taker." ${ }^{23}$ In the 1920 s and 1930s, photographs were becoming the main illustrative medium in magazines and newspapers, and it was necessary to have visual descriptions that would fully express the reality of their subjects, as opposed to simple documentation of them.

Carol Squires' essay in Brandow and Ewing's publication titled "Edward Steichen at Condé Nast Publications" explores the evolution of Steichen as a portrait photographer of the elite. ${ }^{24}$ She states, "as a young man, Steichen had conceived of a project to do portraits of 'Great Men,' something that required time and patience. Among his most revered early subjects was Rodin, whom the photographer visited a year before taking pictures of him." ${ }^{.25}$ Steichen's ambition to clearly express a personality is again evident in the thoughtful consideration of his approach. Using formal analysis of images, Squires addresses various qualities of Steichen's

\footnotetext{
${ }^{20}$ William A. Ewing, "Preface and Acknowledgements: In High Fashion" in Edward Steichen: In High Fashion, the Condé Nast Years, 1923-1937 (Minneapolis: FEP Editions LLC in association with W.W. Norton \& Co., 2007), 14.

${ }^{21}$ Ibid., 11.

${ }^{22}$ William A. Ewing, "In Perfect Conjunction" in Edward Steichen: In High Fashion, the Condé Nast Years, 19231937 (Minneapolis: FEP Editions LLC in association with W.W. Norton \& Co., 2007).

${ }^{23}$ Ibid., 25.

${ }^{24}$ Carol Squires, "Edward Steichen at Condé Nast Publications," in Edward Steichen: In High Fashion, the Condé Nast Years, 1923-1937 (Minneapolis: FEP Editions LLC in association with W.W. Norton \& Co., 2007).

${ }^{25}$ Ibid., 114.
} 
photographs, such as the use of key light and contrast to visually develop the personality he was depicting. She goes on to say, "in portraits of artists and statesmen alike, Steichen often cast a frosty glow of light evoking greatness." ${ }^{26}$ Truly knowledgeable of his medium, Steichen used the tools of his trade to accurately depict the personality he had taken the time to understand. Brandow's book features additional essays on Steichen's use of the fashion model in his Vogue portraits as well as the value of experimental studio lighting concepts to develop his aesthetic. While these essays were informative, they were not directly related to the celebrity portraiture. The last piece of pertinent information to come from the Brandow and Ewing book is the index, "Models and Sitters: A Who's Who," complied by Nathalie Herschdorfer. ${ }^{27}$ This was a helpful reference to identify names that appeared on the file folders and expand the information on the project spreadsheet.

Lastly, biographical timelines were also of value to my research on Steichen's years at Condé Nast. For example, the "Edward Steichen" entry found on vogupedia.com makes it clear in the timeline that part of the reason Steichen was hired so quickly was due to the "sudden departure of Adolphe de Meyer [first staffed Vogue and Vanity Fair photographer, 19131921]. ${ }^{, 28}$ The fortunate timing of Steichen's return to New York and his letter correcting Crowningshield's statement all worked together in his favor. Grace M. Mayer, assistant to Steichen at MoMA and later Curator of the Department of Photography (1962-1968), created a timeline for the 1963 MoMA publication, Steichen The Photographer, which provided considerable insight into his photographic and artistic pursuits during his time at Condé Nast. ${ }^{29}$

\footnotetext{
${ }^{26}$ Ibid., 117.

${ }^{27}$ Nathalie Herschdorfer, "Models and Sitters: A Who's Who," in Edward Steichen: In High Fashion, the Condé Nast Years, 1923-1937 (Minneapolis: FEP Editions LLC in association with W.W. Norton \& Co., 2007).

${ }^{28}$ Voguepedia. "Photographers: Edward Steichen," http://www.vogue.com/voguepedia/Edward_Steichen (accessed February-May 2013).

${ }^{29}$ Mayer, "Biographical Timeline."
} 
All of the sources listed above have provided insight into the fourteen years Steichen worked for Condé Nast. While fourteen years at Condé Nast Publications could be considered the greatest accomplishment of any single photographer's career, it is just one part of Edward Steichen's many achievements in photography. A careful study of the available sources enhances a comprehensive analysis of his work, the decisions that led him to commercial portraiture, and how those decisions transformed his image making.

\subsection{Processing Archives}

Many articles, books, and publications exist on recommendations for managing photographic collections and archives. Since the Edward Steichen material is a subset of the larger George Eastman House collection with a great deal of research potential, the main goals of processing were to allow researchers access, while improving preservation methods of the materials. With these ideas in mind, the review of literature was focused on processing collections with accessibility and preservation as the main goals. Research into the literature of archival processing was made in two main approaches, theoretical and practical.

James O' Toole, in his article, “On the Idea of Uniqueness," discusses the distinctiveness of objects as the basis on which to organize a collection. ${ }^{30}$ While his article does not address photographs specifically, he suggests that materials in archives are only as valuable as the care that they are given, based on perceived value. He states, "archivists rest secure in the knowledge that the uniqueness of the materials in their care justifies their efforts and makes their collections valuable....The importance of preserving those unique records seems morally unassailable, even if programs to accomplish that preservation are not... as fully supported as they deserve to be." ${ }^{\prime 31}$

\footnotetext{
${ }^{30}$ James M. O’Toole, “On the Idea of Uniqueness,” The American Archivist (Vol. 57, No. 4, Fall, 1994).

${ }^{31}$ Ibid., 633.
} 
An understanding of why materials are being preserved should be the first step in the management of objects, as it fuels the choices institutions make in terms of access and preservation. Thus, both uniqueness and perceived value are factors in theorizing how collections should be handled and processed.

Preserving objects with access in mind has led to the modern theory of "more product, less process," an idea that has been explored in articles such as Mark A. Greene and Dennis Meissner's, "More Product, Less Process: Revamping Traditional Archival Processing." 32 Green and Meissner argue that item-level processing is a far too complex and time-consuming process for the quantity and quality of objects that most collections hold. They argue for a scrutiny on the part of the funding institutions to determine the long-term value of item-level processing. They state, "we expect that any project that seeks funding for [item-level processing] must have a basis on which to calculate the real cost differentials imposed by that more intensive level of work."33 Green and Meissner take the approach that value perception determines the longevity of a collection's management and financial support.

At the opposite end of the spectrum, sources for practical processing recommendations come from instructions found in conservation manuals. One such manual, Mary Lynn Ritzenthaler's, Preserving Archives and Manuscripts, suggests that keeping objects in their original, non-archival housings may be more destructive than necessary and some items should not be kept simply for the sake of keeping. ${ }^{34}$ She states, "while a collection is being organized, damaging fasteners and other items viewed as extraneous or of no archival significance should be removed...materials requiring special protections, such as photographs...should be

\footnotetext{
${ }^{32}$ Mark A. Greene and Dennis Meissner, "More Product, Less Process: Revamping Traditional Archival Processing" (The American Archivist Vol. 68, No. 2, Fall-Winter, 2005).

${ }^{33}$ Ibid., 254.

${ }^{34}$ Mary Lynn Ritzenthaler, Preserving Archives and Manuscripts (Chicago: Society of American Archivists, 1993), 110
} 
individually sleeved at this time also." ${ }^{, 35}$ Ritzenthaler and Diane Vogt O'Connor's, Photographs: Archival Care and Management, serves as an additional practical guide and is a large volume dedicated to topics within photographs collections such as appraisal, arrangement, description, digitization, and reference. ${ }^{36}$ The information organized in this guide is appropriate for both large repositories, and smaller photographs collections and is an industry standard for processing.

Since collections' processing in archives emphasizes access and preservation, additional steps, mainly cataloguing and creating a finding aid, should be implemented. At George Eastman House, cataloguing is an essential step for applying information to objects. Tasha Lutek, in her 2010 thesis for Ryerson University, discusses cataloguing as a necessary step towards access but also for the preservation of objects through a case study. ${ }^{37}$ She states, "Within the archive, the first point of entry for a researcher to an object is often through the database. In the example of [Eastman House], this database is The Museum System (TMS). TMS allows its users to search through a variety of fields and to refine searches, thus presenting the user with a multitude of options and information." ${ }^{38}$ The catalogue record, given to each individual object stresses the importance of cataloguing to the processing of the collection. A finding aid, the next step in collection access, is defined by Lance Stuchell of the Benson Ford Research Center as the "primary descriptive tool providing access to archival collections," continuing on to say the structure and content of a finding aid will depend upon the amount of processing of the collection. ${ }^{39}$ He states, “a collection is 'processed' when an individual can make productive use

\footnotetext{
${ }^{35}$ Ibid., 110-112.

${ }^{36}$ Mary Lynn Ritzenthaler and Diane Vogt-O’Connor, Photographs: Archival Care and Management (Chicago: Society of American Archivists, 2006).

${ }^{37}$ Tasha Lutek, “The Specimens Box: A Case Study in Cataloguing at George Eastman House” (master's thesis, Ryerson University, 2010).

${ }^{38}$ Ibid., 22.

${ }^{39}$ Lance Stuchell, "Creating Finding Aids at the Benson Ford Research Center” (Dearborn, MI: Benson Ford Research Center, The Henry Ford, 2012).
} 
of it for research.. ${ }^{, 0}$ Ultimately, an archive makes a collection available for research when the collection has been catalogued and the concisely described in the collection finding aid.

Catalogue records allow the researcher enough information on the objects to decide whether or not researching it at a physical level necessary. If the researcher decides that handling the object is or is not necessary after consulting both the catalogue record and the finding aid, then both tools have served their purposes for access and preservation.

Finally, research was conducted to distinguish between conservation and preservation during the processing activities. This was a necessary component to the research as contact prints were adhered to envelopes and could not be removed without damaging the prints. In order to preserve them for future research, a conservator is needed to complete the appropriate work and remove contact prints from the envelopes to which they are adhered. Sources such as Bertrand Lavédrine's "Photographs of the Past: Process and Preservation," provides suggestions for preserving photographs in their current state and to keep them from further deterioration. ${ }^{41} \mathrm{He}$ discusses the role of the conservator later in the book, stating, "any intervention should be done cautiously and requires the advice or the skills of a photograph conservator," a specialized skill developed through training. ${ }^{42}$ The Library of Congress goes one step further than simply the recommendation of a conservator. The photographs preservation webpage, titled "Care, Handling and Storage of Photographs," provides a link to the American Institute for Conservation of Historic and Artistic Works, which includes a directory of conservators by locations and specialties. ${ }^{43}$ If objects need conservation before they can continue to be processed,

\footnotetext{
${ }^{40}$ Ibid., 2.

${ }^{41}$ Bertrand Lavédrine, Photographs of the Past: Process and Preservation (Los Angeles: The Getty Conservation Institute 2009).

${ }^{42}$ Ibid., 302.

${ }^{43}$ The Library of Congress. "Preservation: Care, Handling, and Storage of Photographs" http://www.loc.gov/preservation/care/photo.html (Accessed July 25, 2013); http://www.conservation-us.org/
} 
archives have the responsibility of taking this step to insure the preservation of objects within their care.

Research on archival care and management covers a wide range of topics, all under the umbrella of access and preservation. With these goals at the forefront of collections processing, objects are approached with their continued use in mind.

\subsection{Identifying, Handling, and Storing Sheet Film}

There are several books that serve as excellent sources on flexible film base materials, including two published by the Image Permanence Institute: James Reilly's Storage Guide for Acetate Film and María Fernanda Valverde's Photographic Negatives: Nature and Evolution of Processes ${ }^{44}$ Valverde's booklet includes chapters on cellulose nitrate and cellulose acetate film negatives, giving a brief history for both. She also includes a diagram of the six stages of nitrate film deterioration by color, odor and physical characteristics. ${ }^{45}$ This diagram is an exceptionally useful tool to identify nitrate film by the characteristics of deterioration.

Most acetate and nitrate film identification guides take the form of diagrams with notch code illustrations, edge printing samples, and a list of deterioration characteristics. Two cohesive guides used for this project were the Northeast Document Conservations Center (NEDCC)'s, "A Short Guide to Film Base Photographic Materials: Identification, Care and Duplication,” and Monique C. Fischer and Andrew Robb's, "Guidelines for Care \& Identification of Film Base Photographic Materials." ${ }^{46}$ Both include illustrated diagrams of film notch codes as well as

\footnotetext{
${ }^{44}$ James M. Reilly, IPI Storage Guide for Acetate Film (Rochester, NY: IPI, 1993); María Fernanda Valverde, Photographic Negatives: Nature and Evolution of Processes (Rochester, NY: IPI, 2005).

${ }^{45}$ Valverde, Photographic Negatives, 21.

46 "Preservation Leaflet 5.1 A Short Guide to Film Base Photographic Materials: Identification and Care and Duplication" (Andover, MD: NEDCC, 2008); Monique C. Fischer and Andrew Robb, "Guidelines for Care \& Identification of Film-Base Photographic Materials," In Topics in Photographic Preservation, Volume 5, (Washington, DC: AIC, 1993).
} 
dimensions and edge printing text, which was helpful in identifying different brands of sheet film. Andrew Robb's, “Identification of Film-Base Photographic Materials: Flow Chart" served as a guide for identifying nitrate films from acetate films. ${ }^{47}$

There are several important sources available on handling and storage recommendations of acetate and nitrate based films. J.M. Calhoun's 1953 "Storage of Nitrate Amateur StillCamera Film Negatives," continues to be a good foundation of information. ${ }^{48}$ Calhoun's article is an exceedingly helpful reference on the chemical composition of nitrate films. It includes tables and figures with photographic illustrations depicting the stages of nitrate deterioration. It also explains the four methods Calhoun recommends to identify nitrate negatives: edge printing, chemical testing, float testing and burn testing. ${ }^{49}$ These identification methods are still recommended by conservators, historians and chemists today. ${ }^{50}$ Another succinct identification guide was found in the National Park Service's September 1999 Conserve O Gram, titled, "Identification of Film-Base Photographic Materials," a monthly circular published by the National Park Service's Museum Management Program ${ }^{51}$ This guide, the flow chart created by Andrew Robb, as well as the NEDCC Preservation Leaflet 5.1 were the documents most referenced for this practical project. Constantly referring to these articles was necessary to reinforce the methods of identification. ${ }^{52}$

Health and safety concerns are also an important consideration for processing nitrate materials. The National Park Service's June 2003 and August 2004 Conserve O Gram both

\footnotetext{
${ }^{47}$ Andrew Robb, "Identification of Film-Base Photographic Materials: Flow Chart" (Andover, MD: NEDCC, 2008).

${ }^{48}$ J.M. Calhoun, "Storage of Nitrate Amateur Still-Camera Film Negatives," in The Journal of the Biological Photographic Association (August 1953).

${ }^{49}$ Ibid., 7. Destructive testing was not used to identify nitrate base film material due to obvious ramifications of such testing. Use of destructive testing as an identification method on collections material is not advised without proper knowledge, and should only be undertaken with the permission of the institution.

${ }^{50}$ For instance, the recent identification guide published by the NEDCC suggests the same methods as Calhoun.

51 "Identification of Film-Base Photographic Materials," Conserve O' Gram, September 1999 (Washington, DC: National Park Service Museum Management Program, 1999).

${ }^{52}$ Robb, "Flow Chart"; NEDCC, "Preservation Leaflet. 5.1"
} 
address the care and handling of nitrate films. Lists, in the form of "do's and don't's" appear in both publications as simple reference guides. ${ }^{53}$ "Caring for Cellulose Nitrate Film," highlights physical ailments associated with prolonged exposure to nitrate materials, as well as federal regulations for shipping and moving nitrate. ${ }^{54}$ Identification of nitrate film negatives, as well as the safe handling and storage methods protect not only archive staff and researchers, but also the objects. This extends to both the nitrate negatives themselves and also objects kept in contact with, or in close proximity to them, as "they present a great potential hazard to other materials because of their flammability." ${ }^{, 55}$ Understanding the physical components of the materials keeps the collection, as a whole, from unnecessary deterioration or damage related to chemical or environmental changes.

Once collection materials have been properly identified and separated and health and safety concerns have been addressed, items should be housed using archival materials. In terms of storage conditions, the NEDCC recommends three layers of storage for both acetate and nitrate film base materials. "Negatives should be placed in sleeves, sleeves in a box or drawer, and these boxes or drawers on shelves or in a cabinet" materials. ${ }^{56}$ For nitrate materials, the NEDCC recommends "cellulose nitrate negatives be stored separately from other negatives in a collection," as chemical reactions can speed up deterioration, and flammable characteristics of nitrate film risk safety of other collections objects. ${ }^{57}$

Deterioration is a concern for both acetate and nitrate films. Deterioration of nitrate film is more imminent due to its chemical components, specifically, "nitric oxide, nitrous oxide, and

\footnotetext{
53 "Handling and Shipping Cellulose Nitrate Film," Conserve O' Gram, June 2003 (Washington, DC: National Park Service Museum Management Program, 2003); "Caring for Cellulose Nitrate Film," Conserve O' Gram, August 2003 (Washington, DC: National Park Service Museum Management Program, 2004).

${ }^{54}$ NPS, "Caring for," 2-3.

${ }^{55}$ NEDCC, "Preservation Leaflet 5.1," 4.

${ }^{56}$ Ibid.

${ }^{57}$ Ibid., 2
} 
nitrous dioxide, [all of which are] released as gases from the decomposition of cellulose nitrate. ${ }^{.58}$ When nitrate films are stored in the presence of high humidity, the gases combine with water in the air to form nitric acid, and as a result, foster the deterioration process and may cause damage to other objects. "The formation of nitric acid act to further degrade the cellulose nitrate film...they should be stored in a controlled environment of relatively low humidity, or ideally in cold storage.$^{59}$ The National Fire Protection Association recommends compartmentalization of nitrate materials within a cold storage vault, where temperature and relative humidity can be precisely controlled.$^{60}$ Within cold storage, the National Film Preservation Foundation notes, "for nitrate film, the ISO standards recommend a maximum temperature of 36 degrees Fahrenheit and a relative humidity between $20 \%$ and $30 \% .{ }^{, 61}$

Acetate negative deterioration occurs "when stored in a poor environment at high heat and humidity, or exposed to acidic vapors from nearby degrading film, [and] undergoes chemical reactions within the plastic support to form acetic acid. ${ }^{, 62}$ In order to avoid this, the three-layer approach (discussed above) is the best method. The NEDCC recommends, "individual, seamless, high alpha cellulose content paper enclosures...disposal of used enclosures is recommended in order to avoid reuse. ${ }^{\prime 63}$ An example of putting this recommendation into practice is to return the folders in which each negative was sleeved to the original bankers box (see Chapter 3.2), rather than keeping the folders among the collections material for future use. This prevents cross contaminating negatives. Similar to nitrate, a cold environment is recommended for storing

\footnotetext{
${ }^{58}$ Ibid.

${ }^{59}$ Ibid.

${ }^{60}$ National Fire Protection Association, "Standard for the Storage and Handling of Cellulose Nitrate Film, NFPA 40" (Quincy, MA: National Fire Protection Association, 2001), www.nfpa.org (Accessed July 25, 2013).

${ }^{61}$ The National Film Preservation Foundation, "6.5 Storing Nitrate Film, in The Film Preservation Guide: The Basics for Archives, Libraries, and Museums (San Francisco, CA: The National Film Preservation Foundation, 2004), 65. http://www.filmpreservation.org/userfiles/image/PDFs/fpg_6.pdf (Accessed July 31, 2013).

${ }^{62}$ Ibid., 3.

${ }^{63}$ Ibid., 4.
} 
acetate negatives. In the Image Permanence Institute's "Storage Guide for Acetate Film," James Reilly states that cold storage could extend the life of acetate negatives. ${ }^{64}$ If kept in cold storage at a temperature of 40 degrees Fahrenheit and 50 percent relative humidity, Reilly predicts that it will take roughly 50 years for the acidity in acetate film to double, therefore, cold storage limits the progression of vinegar syndrome. ${ }^{65}$

The review of literature conducted above provided a knowledge base from which to proceed with processing the collection of negatives and contact prints. The facts concerning nitrate and acetate materials were taken into consideration when handling, processing and storing the materials. The following chapter outlines the steps to process the collection.

\footnotetext{
${ }^{64}$ James Reilly, The IPI Storage Guide for Acetate Film (Rochester, NY: Image Permanence Institute, 1993).

${ }^{65}$ Ibid., 6.
} 


\section{Methodology}

This chapter includes expanded detail pertaining to the life of the celebrity material at George Eastman House, beginning with the 2002 loan by Joanna Steichen. It discusses how the original processing instructions were adapted and changed. In addition, it details the process and steps for identifying matches between the celebrity images and published Vanity Fair images. It is important to note that this methodology was applied to the celebrity portrait negatives and contact prints only, and was not used to process other materials that were received as part of the original donation. Employing this methodology to non-celebrity materials from the original donation is discussed in the conclusion of this thesis.

\subsection{Background and Arrangement}

Before I could continue processing the materials, it was important to understand how they arrived at Eastman House and to conduct a survey of the work that had been completed on the material to date. In 2002, Joanna Steichen gifted a collection of materials related to Edward Steichen to Eastman House. The deed of gift stipulated transfer of copyright and the permanent loan until the collection became property of the museum at the time of her death. ${ }^{66}$ The loaned property included $2.25 \times 2.25$-inch to $8 \times 10$-inch gelatin silver contact prints adhered to folders within which companion gelatin silver (acetate, nitrate and color separation) negatives were sleeved. This collection arrived at the museum housed in bankers boxes that contained file folders (Figure 2) organized primarily in alphabetical order by sitter's last name (Figure 3). The file folders exhibited several varieties of handwritten notes, including the sitter's name, a nondescript date, and inscriptions such as "Vogue" or "V.F." The subjects of these prints included a

\footnotetext{
${ }^{66}$ Deed of gift to George Eastman House, "Section II. Loaned Property, A. Loan," (2002) 1. Reprinted with permission from The Estate of Edward Steichen.
} 
plethora of illustrious stage and screen actors and actresses, socialites, politicians, authors,

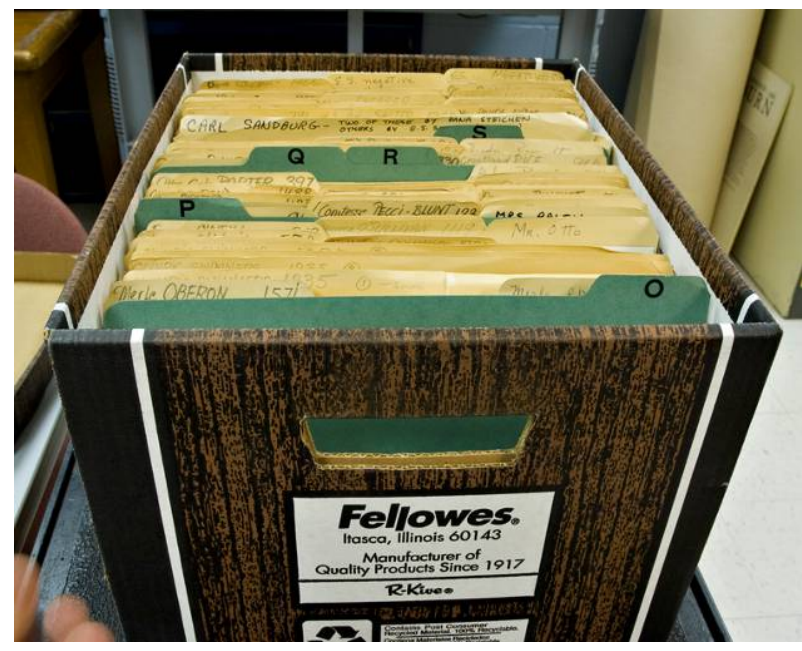

Figure 2: Bankers box of unprocessed celebrity material.

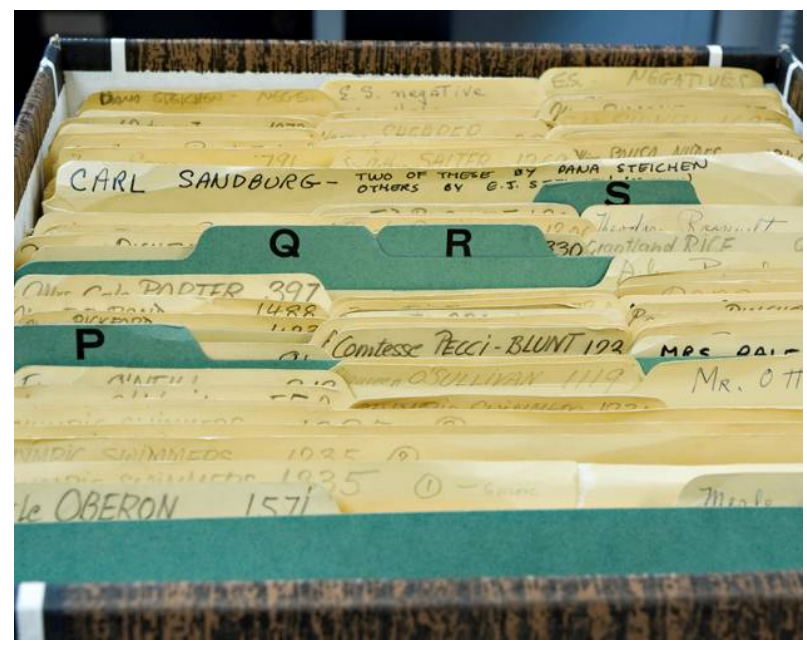

Figure 3: File folders with original handwritten inscriptions. musicians, athletes, and multiple portraits of Edward Steichen himself.

The Museum began processing this material in 2002 with an inventory and object count in order to understand the scope and contents. In 2006 and 2007, Ryerson student residents further processed the material as part of an ISO project directed by the Collection Management Department. ${ }^{67}$ The objects were assigned a run of loan numbers, L2001:2627 through L2001:3747, with the "L" indicating loaned material. The objects were divided into two lot numbers: one for negatives, and one for contact prints. Each lot number was assigned to a file folder of objects with images of the sitter of a Steichen portrait session. ${ }^{68}$ Item-level numbers were determined based on the total number of either negatives or contact prints within the file folder. ${ }^{69}$ For example, L2001:3210:0001-0012 and L2001:3211:0001-0011 identifies two lot numbers for the file folder of objects identified as the novelist, Sinclair Lewis. Twelve negatives were present, along with eleven contact prints. Therefore, 3210 is the lot number for the group of negatives of Sinclair

\footnotetext{
${ }^{67}$ ISO-Institutional Service Opportunity.

${ }^{68}$ In this case, lot numbers refers to the four digit numbers following L2001.

${ }^{69}$ In this case, item-level numbers refer to the four digit numbers following the lot number.
} 
Lewis, and 0001-0012 are the item-level numbers given to each of the twelve negatives present. Likewise, in L2001:3211:0001-0011, 3211 refers to the group of contact prints of Sinclair Lewis, and 0001-0011 refers to each of the eleven contact prints of the novelist. A spreadsheet created by the Collection Management Department listed these numbers based on their initial object count and provided a space to transfer information from the file folders to the numbered list. Students processed the materials by making an itemized count of the objects in each lot, assigning numbers to each individual object, transferring information to the spreadsheet from the file folders and rehousing the prints and negatives into new sleeves and boxes. Fields included within the spreadsheet were: description (including sitter, date, and other handwritten information), total object count within each lot, date the objects were assigned numbers (the date objects were physically numbered), name of the person assigning the numbers, and a field for film notch codes (as various types of negative bases were present). This information transfer was a crucial step in the process, as processing the objects separated them from their original housings (file folders and bankers boxes within which they arrived) that carried information associated with them. This work completed processing of nearly half of the material. File folders A-L of the celebrity negatives and contact prints were rehoused and information transferred to the spreadsheet.

At the time of Mrs. Steichen's death in July of 2010, "all right, title, and interest to, and in the Loaned Property, including copyright...transferred to the Museum free and clear." Approximately two years passed in which the material sat unprocessed and unhandled, while awaiting completion of the paperwork giving ownership of the Steichen gift to Eastman House.

\footnotetext{
${ }^{70}$ Steichen, "Receipt, Release,” 2.
} 


\subsection{Continuation of Processing}

My practical project began to take shape in the fall of 2012 with an analysis of the work that had been done and an assessment of how to continue. By the time I began handling the objects in January of 2013, I had made two critical changes to the processing method previously put into place. First, I noted that the contact prints that were processed prior to my work had been removed from the sleeves, but that damage had occurred as a result of aged double-sided adhesives. While it is unknown at what point these photographs were adhered to the envelopes, my best guess is that this step took place when they were being gathered in the bankers boxes. It is not known if these inscriptions were created by Steichen's own hand or that of an assistant. After a discussion with Taina Meller, Conservator in Charge, and Jamie Allen, Assistant Curator, it was determined that in order to eliminate the risk of further damage, the prints would remain adhered to the sleeves until a separate conservation project could be undertaken to safely remove them. Thus, rather than removing and rehousing the prints, I would only number the prints and return them to the original file folder and bankers box from which they came.

My second change to the original processing instructions was to remove the " $\mathrm{L}$ " from the numbering scheme while continuing with the accession numbers assigned in the spreadsheet. This was a result of the bequest and title transfer to the museum that occurred in 2010. Since the loaned material was now museum property, the accession numbers did not need to be preceded with an "L."

After acquiring approval for the modifications to my instructions, I began to process the remaining objects. ${ }^{71}$ Below is an illustration of the processing method I put into place and used for 2001:3524:0001-0004 and 2001:3525:0001-0004 (lot and item-level numbers for the file

\footnotetext{
${ }^{71}$ For a copy of both the original instructions and my amended version, please see Appendix A and B.
} 
folder of objects identified as Gloria Swanson). Four negatives were present, with four contact prints. Therefore, 2001:3524:0001-0004 is the lot and item-level numbers assigned to the negatives and 2001:3525:0001-0004 is the lot and item-level numbers assigned to the contact prints. The basic methodology is as follows:

1. Remove file folder from bankers box of materials (roughly alphabetical by sitter's last name). Count the number of negatives and number of contact prints. Input these values into the Excel spreadsheet (Figure 4, Table 1).

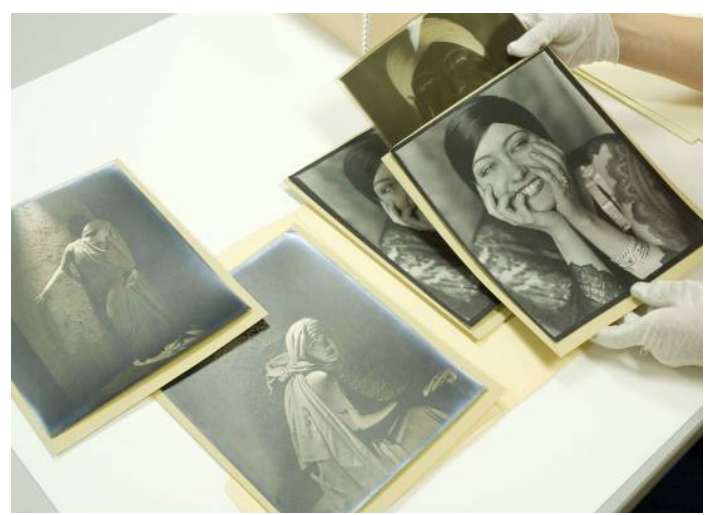

Figure 4: Sample of file folder contents.

\begin{tabular}{|c|c|c|c|c|c|c|}
\hline & & & $\begin{array}{l}\text { Extended Loan from Joanna T. Steichen, } 2000 \text { } \\
\text { Steichen Portrait Negatives - - Numbering Scheme }\end{array}$ & & & \\
\hline Year \# & Lot\# & Sub\# & Descriptions & Count & $\begin{array}{c}\text { Number } \\
\text { Alllocation } \\
\text { Date }\end{array}$ & Name \\
\hline L2001 & 3524 & $0001-4$ & Gloria Swanson - film actress, May 25 1924, \#110. 4 negs. & 4 & $3 / 13 / 13$ & M. Shaw \\
\hline L2001 & 3525 & $0001-4$ & Gloria Swanson - film actress, May $251924, \# 110.4$ prints & 4 & $3 / 13 / 13$ & M. Shaw \\
\hline
\end{tabular}

Table 1: Detail of spreadsheet: Object Count - The highlighted field indicates where object counts were entered.

2. Record any additional handwritten information that appears on the file folder in the "Descriptions" field of the spreadsheet (shoot date, publication name, etc.). Ex: "Gloria Swanson - film actress, May 251924 , \#110" (Table 2).

\begin{tabular}{|c|c|c|c|c|c|c|}
\hline & & & $\begin{array}{l}\text { Extended Loan from Joanna T. Steichen, } 2000 \text { } \\
\text { Steichen Portrait Negatives -- Numbering Scheme }\end{array}$ & & & \\
\hline Year \# & Lot \# & Sub \# & Descriptions & Count & $\begin{array}{c}\text { Number } \\
\text { Allocation } \\
\text { Date }\end{array}$ & Name \\
\hline L2001 & 3524 & $0001-4$ & Gloria Swanson - film actress, May 25 1924, \#110. 4 negs. & 4 & $3 / 13 / 13$ & M. Shaw \\
\hline L2001 & 3525 & $0001-4$ & Gloria Swanson - film actress, May $251924, \# 110.4$ prints & 4 & $3 / 13 / 13$ & M. Shaw \\
\hline
\end{tabular}

Table 2: Detail of spreadsheet: Descriptions - The highlighted field indicates where file folder inscriptions were entered.

3. Write each item-level number (assigned within the spreadsheet) for each negative on a new archival sleeve - one sleeve per negative. Position the folder horizontally, with the opening to the right. Write the accession number on the top right edge of the sleeve, write the subject's name on the top left edge of the sleeve - first name, last name and date by year (if given). 
4. Record the notch code of the negatives in the appropriate spreadsheet field (Table 3).

\begin{tabular}{|l|c|c|c|c|c|}
\hline \multicolumn{1}{|c|}{ Descriptions } & Count & $\begin{array}{c}\text { Number } \\
\text { Allocation } \\
\text { Date }\end{array}$ & Name & & Notch Code \\
\hline Gloria Swanson - film actress, May 25 1924, \#110. 4 negs. & 4 & $3 / 13 / 13$ & M. Shaw & & Unknown manufacturer \\
\hline Gloria Swanson - film actress, May 25 1924, \#110. 4 prints & 4 & $3 / 13 / 13$ & M. Shaw & & $\nabla \nabla$ \\
\hline
\end{tabular}

Table 3: Detail of spreadsheet: Notch Codes -The highlighted field indicates where film notch codes were entered.

5. Place the negative in a new paper sleeve, with the notch code at the top of sleeve, and the emulsion side facing away from sleeve seam (Figure 5).

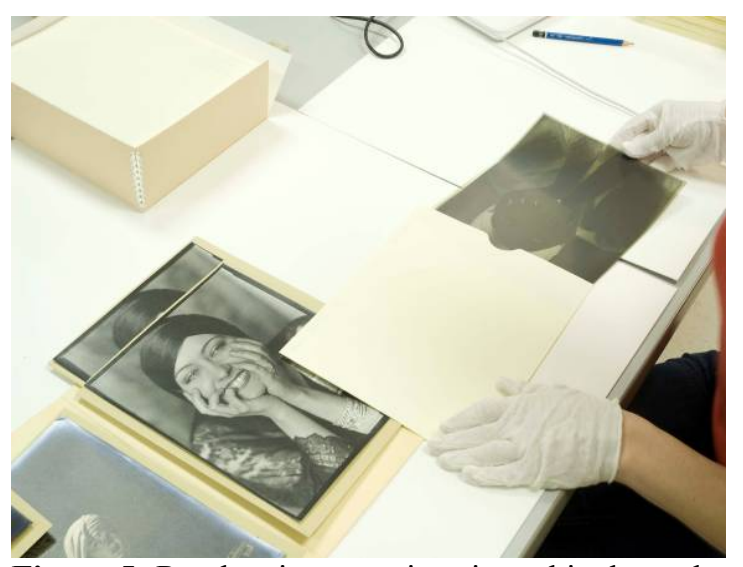

Figure 5: Re-sleeving negatives in archival envelopes.

6. Do not remove the print from the envelope to which it is adhered (Figure 6).

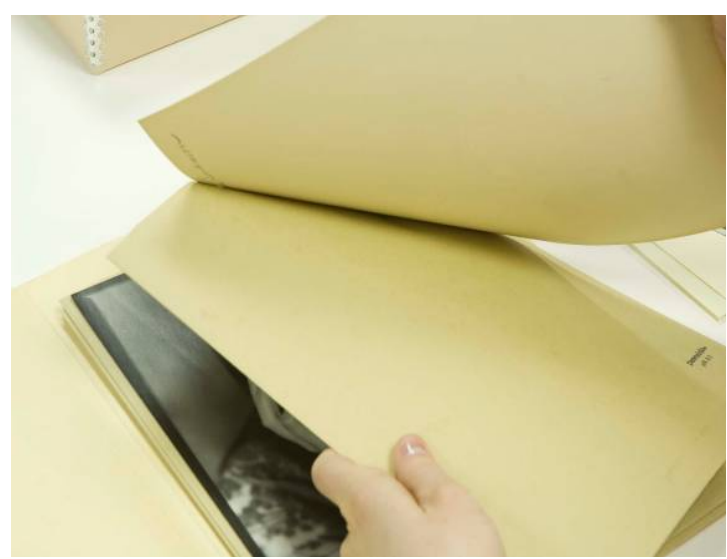

Figure 6: Detail of contact print adhered to original envelope.

7. Write contact print item-level number (given in the spreadsheet) on the lower left verso edge of the print (Figure 7). 


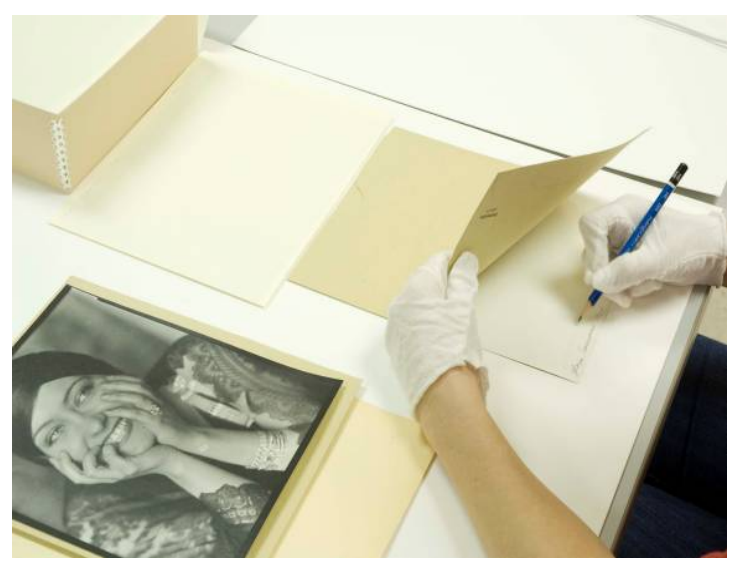

Figure 7: Assigning an accession number to a contact print.

8. Place the newly sleeved negative in a drop-front box designated for negatives. Return the contact print(s) to the original file folder and bankers box from which removed, being careful to keep the file folder in the same order it was removed from the bankers box (Figure 8).

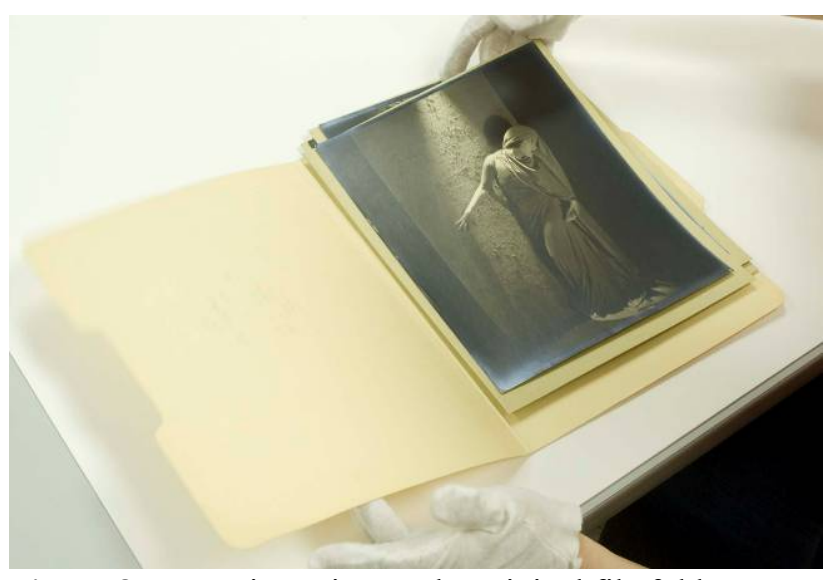

Figure 8: Returning prints to the original file folder.

Step 8 of the processing instructions directs negatives to be stored in new archival boxes. In order to place the negative in the correct archival box, negative base materials had to be identified. Part of this step included identifying the nitrate negative materials and removing them from the bulk of acetate and polyester based materials. Nitrate negatives were placed in a separate box and eventually taken to offsite cold storage. Limited humidity and temperature fluctuations in cold storage keeps nitrate negatives, which are vulnerable to deterioration in uncontrolled environments, from deteriorating, and lower the risk of spontaneous combustion. As a result of the original storage and housing conditions, many of these nitrate negatives were 
already displaying signs of extreme deterioration. As an example in Figure 9, on the left, transmitted light shows advanced Stage 2 nitrate negative deterioration through discoloration. ${ }^{72}$ On the right, in raking light, progressed silver mirroring and warping is evident.
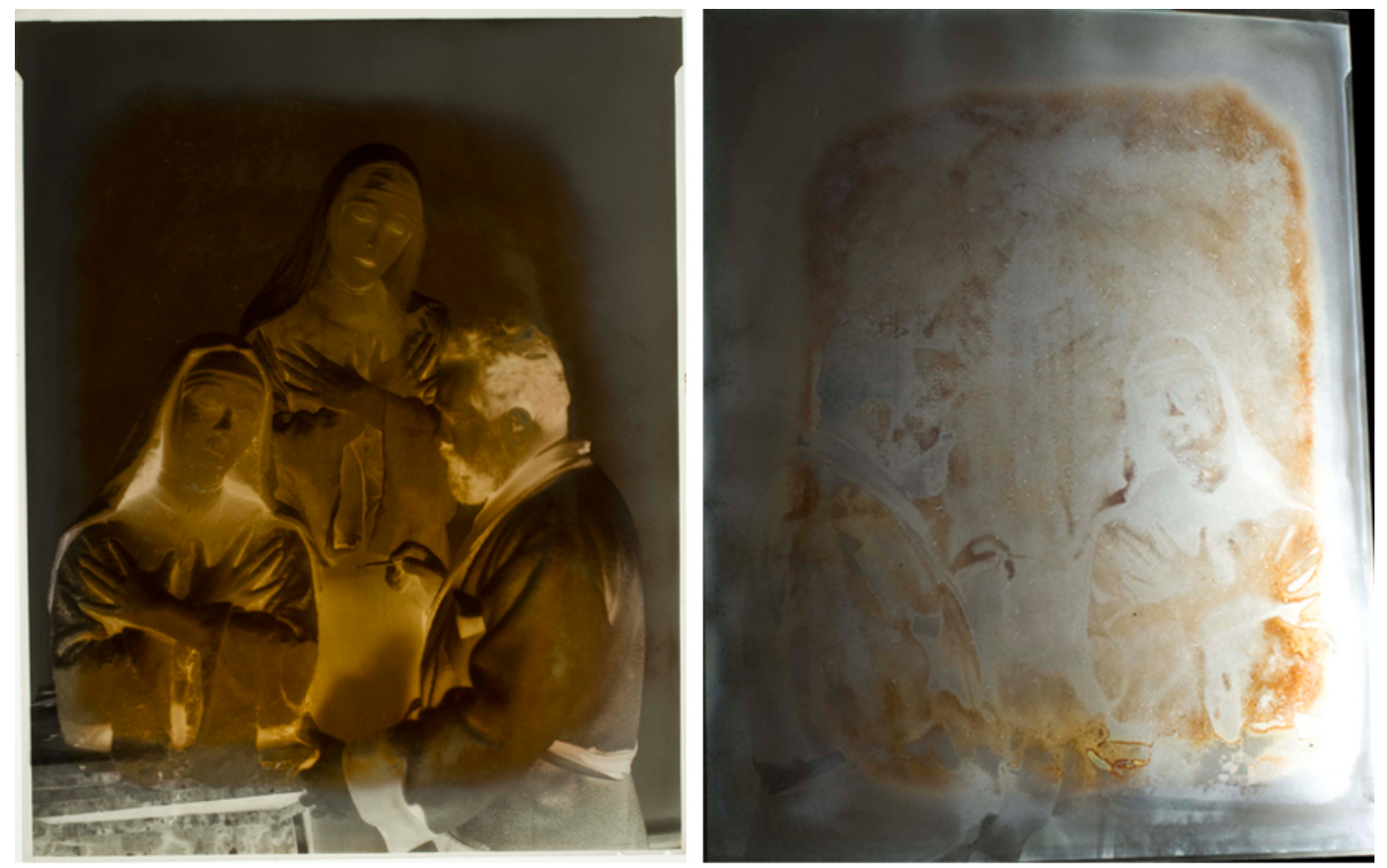

Figure 9

Edward Steichen

Lady Diana Manners as Madonna in "The Miracle," with sculpture and the sculptor Joe Davidson, 1924

Nitrate negative with transmitted light and raking light 2001:3464:0004

\footnotetext{
${ }^{72}$ Valverde, Photographic Negatives, 21.
} 
Another example of deterioration is seen in Figures 10 and 11, a nitrate negative of actress June McCloy. Though not as progressed, this negative shows signs of early Stage 2 nitrate deterioration through discoloration in transmitted light, left, Figure 10 and silver mirroring in raking light, below, Figure 11.
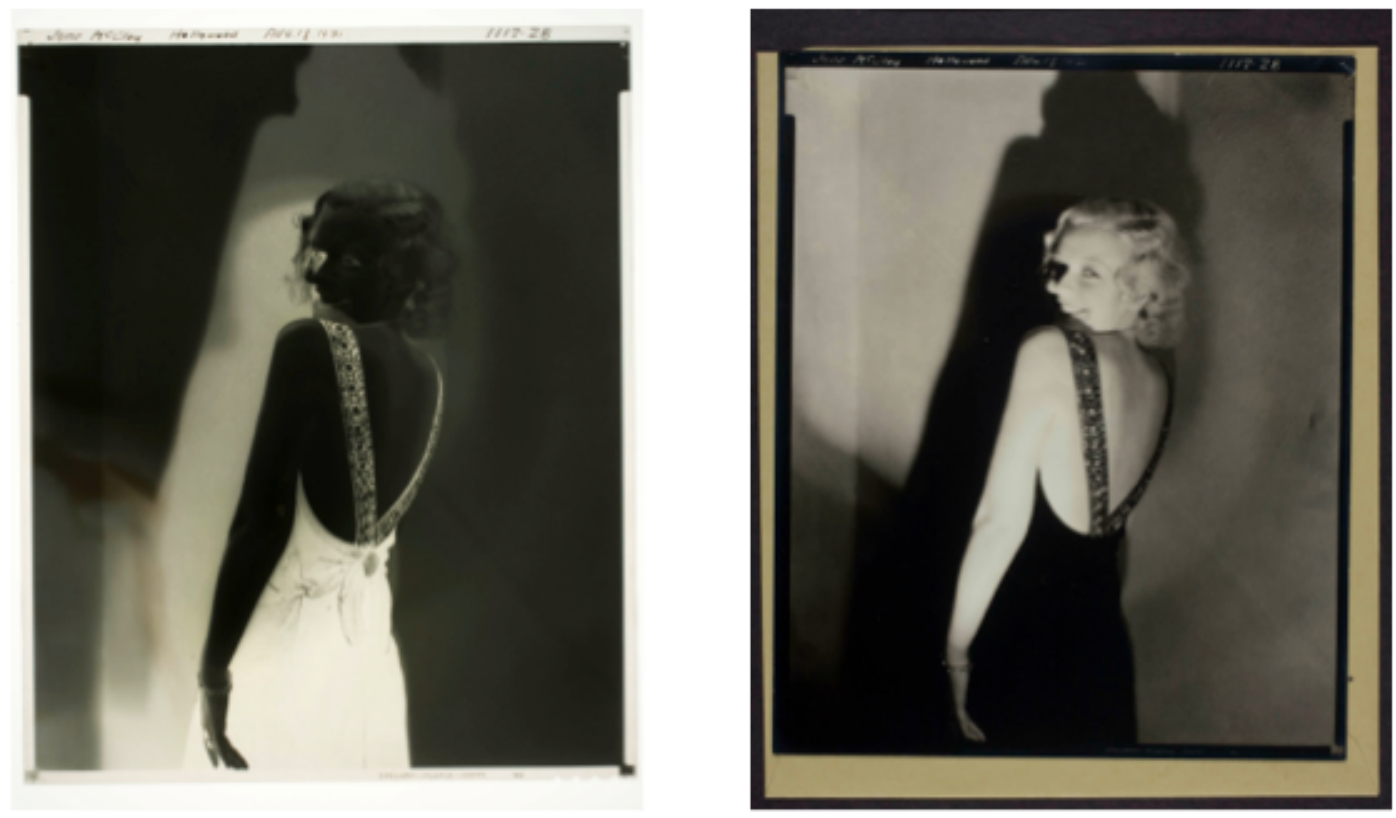

Figure 10

Edward Steichen June McCloy, 1931

Nitrate negative and contact print 2001:3288:0001

2001:3289:0001

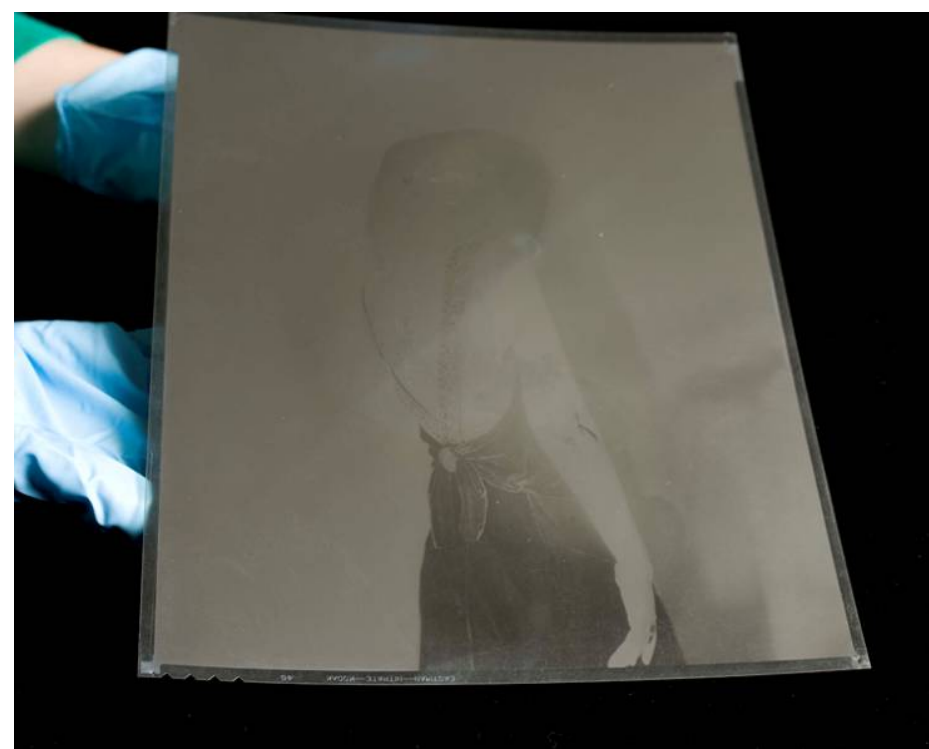

Figure 11

Detail of 2001:3288:0001 negative deterioration. 
According to Kodak Environmental Services, identification of nitrate negatives is a difficult and time-consuming process and any numbers of tests are recommended for identifying film bases. ${ }^{73}$ The only identification methods used in this project were examination of film base notch codes, edge printing, and deterioration characteristics. The two main categories for identifying film bases_-examination and destructive testing — recommended by art conservators Andrew Robb and Monique Fischer can be found in a concise flow chart. ${ }^{74}$ This flow chart and a diagram of known notch codes were the main reference materials for identifying sheet film during this project. For information on film-base identification literature, please see Chapter 2, Literature Survey.

An important part of the processing included maintaining and updating the spreadsheet. In addition to double-checking the information already found in the description field, it was pertinent to double check the actual object count, compared to the stated object count. Additionally, maintaining the notch code field (which included listing every variety of negative base material in the lot) was necessary to keep an accurate record of the types of negative bases present in the collection. While maintaining all these fields, I added fields to the spreadsheet based on the additional research I conducted on the objects. The three fields added to the spreadsheet during this project were: "Vanity Fair, Vogue or other publication appearance," "Nitrate Materials Removed/Date," and "Photographed/Date/File Number" (Table 4). Within the first added field, "Vanity Fair, Vogue or other publication appearance" gives a space for the matches I have made to library materials and a place to continue adding this information from an entire run of Vanity Fair. In the second field, I listed the date and the quantity that nitrate

\footnotetext{
73 "Kodak Environmental Services: Safe Handling, Storage, and Destruction of Nitrate-Based Motion Picture Films," KODAK Publication No. H-182, (Rochester, NY: Eastman Kodak Company, 2003).

${ }^{74}$ Andrew Robb and Monique Fischer, "Identification of Film-Base Photographic Materials: Flow Chart," Topics in Photographic Conservation, American Institute for Conservation, 6, 1995.
} 
negatives were removed from that specific lot, indicating that I had identified nitrate negatives among the lot. Finally, the third field made note of the digitized versions of negatives and contact prints, as well as the date the digital records were made by the photography department at Eastman House (a step in the process with which I assisted). The image numbers given to the digital record are intended to be added to the catalogue record, which is why adding the digital file name to the lot record helps to quickly locate the thumbnail image.

\begin{tabular}{|l|c|l|l|}
\hline Notch Code & $\begin{array}{c}\text { Vanity Fair, Vogue or other publicaton } \\
\text { appearance }\end{array}$ & Nitrate Material Removed/Date & Photographed/Date/File Number \\
\hline
\end{tabular}

Table 4: New fields added to the spreadsheet-The highlighted fields indicates where new fields and titles were added.

The methodology that I applied to this project allowed me to rehouse the prints and negatives; transfer handwritten information from file folders to a larger, more cohesive spreadsheet; identify and separate nitrate negatives to preserve the larger whole; and keep a detailed inventory of the objects for future cataloguing. As a result, I gained the capability of comparing photographs to Library collection holdings, and the expertise to define recommendations for future work with the celebrity materials. My recommendations are laid out in the final chapters and in Appendix I. 


\section{Identifying Matches to Vanity Fair Library Material and Other Publications}

After having researched Edward Steichen's career at Condé Nast Publications and by reading the information found on the original file folders, it was apparent to me that the images may have been made for publication in Vanity Fair, Vogue or other periodicals. Most subjects were photographed multiple times, often during the same portrait session. Identifying the printed version of any of these photographs would expand the information of original intent in making them, which in most cases was, for use as an illustration in a Condé Nast magazine.

As I began processing the negatives and contact prints, I located issues of Vanity Fair magazine within the holdings of the Richard and Ronay Menschel Library at Eastman House. The Library collection holds thirteen issues of this magazine that were published between 1933 and 1935. The table of contents in each issue was particularly helpful in identifying a photograph made by a Condé Nast photographer. Most picture credits appear both within the table of contents and alongside the featured image. Edward Steichen received at least one (often multiple) credit for photographs in each of these thirteen issues. He is credited in capital letters at the bottom right of each photograph as "STEICHEN." Through memory, a good deal of returning to the prints, and searching through the magazines, I was able to link multiple celebrity images held by Eastman House to their published counterpart in Vanity Fair. At this point, to keep track of these appearances, I added a field for "Vanity Fair, Vogue or other publication appearance" into the working spreadsheet.

Cross-referencing collections material with Condé Nast publications allows additional information to be attributed to the objects and broadens the understanding of the purpose of entire portrait sessions. I have started the process of matching the images and made a list of my findings, which can be found in Appendix I. 
A valuable example of associating these negatives and contact prints to their published counterpart can be found through research of Steichen's photographs of the actor Victor Moore. According to the hand-written information on the original file folder, these images were made for Vanity Fair on September 6 1933. I located a reproduction of one of these images in the November 1933 issue of Vanity Fair (Figure 12). ${ }^{75}$
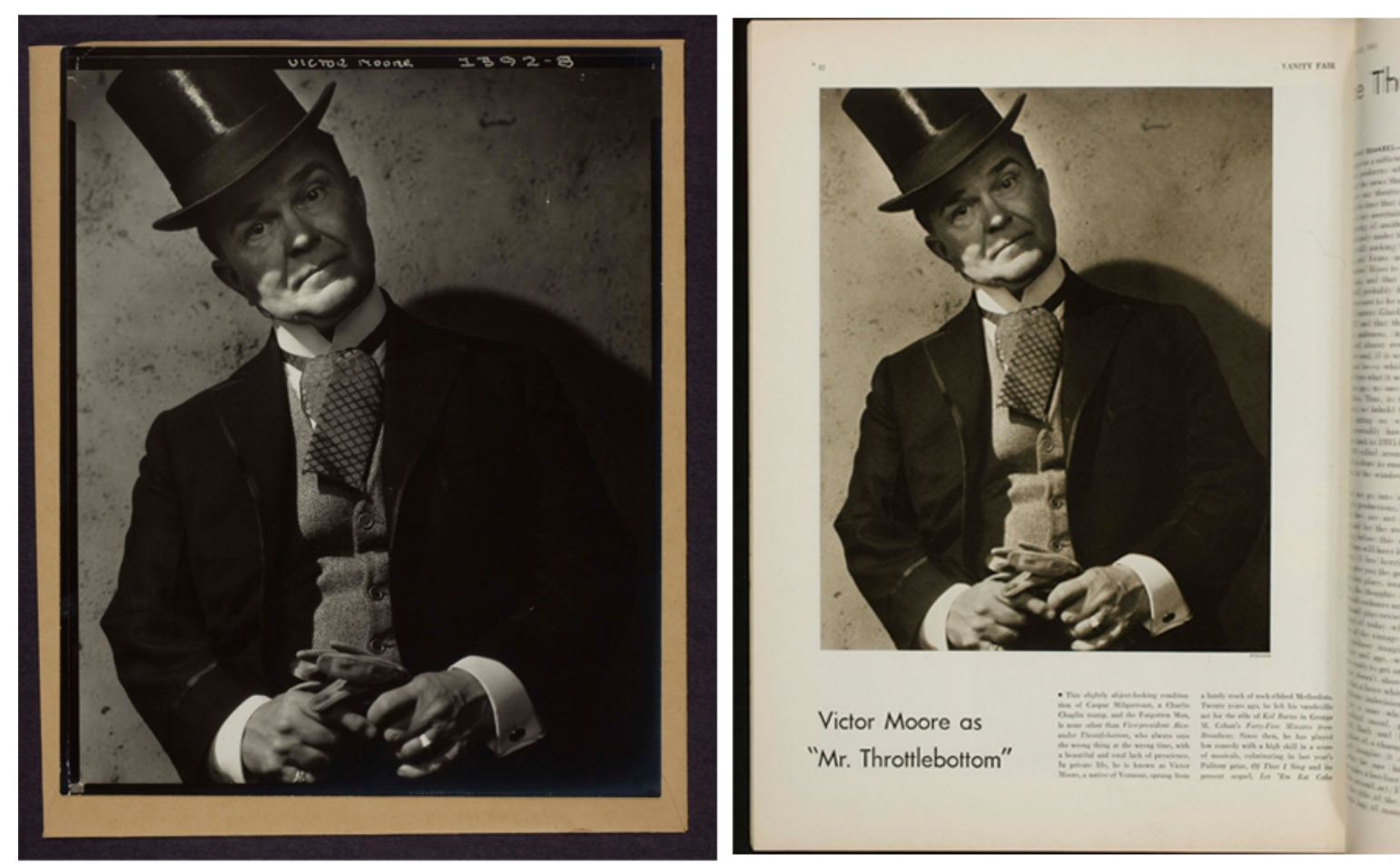

Figure 12

(Left)

Edward Steichen Victor Moore as Alexander Throttlebottom in “Of Thee I Sing," 1933

Contact print, 2001:3361:0001

(Right)

Vanity Fair, November 1933, Page 42 Richard and Ronay Menschel Library George Eastman House Collection

\footnotetext{
75،"Victor Moore as 'Mr Throttlebottom.'” Vanity Fair, November 1933, 42.
} 
Within the collections material, Lot 2001:3360 contains three negatives and 2001:3361 contains three corresponding contact prints of Moore. The photograph itself yields no information on the reason for the portrait, and at first glance, seems to be portrait of Moore himself. However, referencing the article in which this image appears, titled, "Victor Moore as 'Mr Throttlebottom," reveals that this is a photograph of a character Moore is portraying. ${ }^{76}$ An Internet search titled "Victor Moore as Alexander Throttlebottom" links these names to the 1931 Ira Gershwin musical, "Of Thee I Sing," a parody on presidential campaigning (also mentioned in the article, but not directly associated with the image), in which Moore's character was the vice presidential candidate to William Gaxton's character, "John P. Wintergreen."77 The other two images from Steichen and Moore's portrait session, images that were not selected for publication, show Moore wearing a sandwich board that reads, "John P. Wintergreen and Co." (Figure 13).
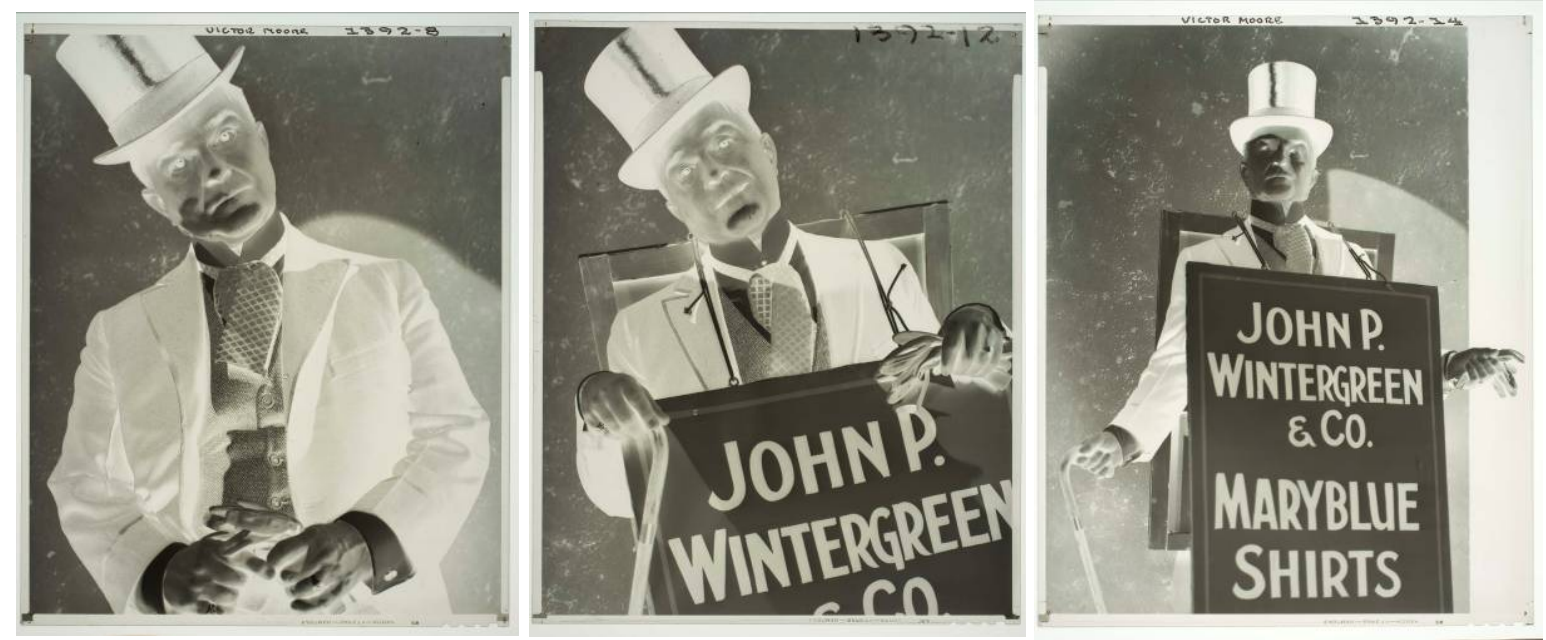

Figure 13

Edward Steichen

Victor Moore as Alexander Throttlebottom in “Of Thee I Sing," 1933

Negatives

2001:3360:0001

2001:3360:0002

2001:3360:0003

\footnotetext{
${ }^{76}$ Ibid.

77 “'Of Thee I Sing,” Wikipedia entry last modified March 7, 2013, http://en.wikipedia.org/wiki/Of_Thee_I_Sing
} 
This information, including the name of Moore's character and the title of the play, would not have been associated to all three images had it not been for locating the Vanity Fair article in which this portrait appeared.

A further search of the production's title, "Of Thee I Sing," on the Internet Broadway Database shows that this musical ran from December 26, 1931 to January 14, 1933 with 441 performances. ${ }^{78}$ At the time of the shoot, "Of Thee I Sing" was four months from closing, and at the time of the Vanity Fair publication; the production was two months from closing. Due to its enormous Broadway success, and having been awarded the 1932 Pulitzer Prize for Drama, Moore would have been a recognizable figure on the stage, and his portrayal of Throttlebottom a familiar performance.

Since $8 \times 10$-inch negatives had to be individually loaded and exposed, photographers employed careful counting and recording methods. In this case, all three images from this shoot are given the session number "1392" in Steichen's numbering system. They also appear to have sequence numbers at the top of the negatives (1392-8, 1392-12, and 1392-14). Whether or not these are the sequential order in which the photographs were made and where image numbers 1$7,10-11$, and 13 exist (if they exist), a researcher can expand the understanding of the reason for the portrait session by comparing the images not chosen for publication to the published version. The example above proves that identifying specific images in the collection that have been printed in a Condé Nast Publication inform the original intention of image making, and outlines a sample research topic for other lots within the Steichen material.

\footnotetext{
78 “Of Thee I Sing,”(The Broadway League, 2013). http://www.ibdb.com/production.php?id=11468 (accessed February - May 2013).
} 


\section{Recommendations for Continued Work/Conclusions}

This thesis presented the continued work on a collection of Edward Steichen's celebrity portraits held at Eastman House. While this work accomplished a large phase of processing, the project also proved that many more stages are needed to completely process the material, and eventually reach a stage where the objects can be used to their fullest potential. This chapter evaluates the work that has been completed to-date and outlines recommendations for continued work that should be completed on the celebrity portrait materials. My recommendations for processing the remaining objects in the Steichen donation can be outlined as follows: complete processing of the non-celebrity related materials in the original 2002 donation; conserve the prints adhered to the envelopes; and catalogue and continue to establish connections between the objects and the magazines.

The object count within the celebrity material is well over 3000 objects. The scope of this project was carefully considered, given the large volume of objects. Previous work on the collection proved that this process requires focused effort. Only half of the celebrity material had been processed at the time I approached it. Since the celebrity portraits are only a portion of the original donation from Joanna Steichen, I recommend applying the revised methodology I have described in Chapter 3.2 and the step-by-step instructions found in Appendix B to process the remainder of the materials. Creating lot and item-level numbers, as well as identifying nitrate negatives and consolidating that information into a spreadsheet is necessary to complete the transfer of information. Storing prints in archival boxes and making them accessible through well-defined labeling elongates the life of the objects and allows the Department of Photographs to preserve the collection for future research. 
While the main result of this applied project was physical numbering of all negatives and prints in the celebrity material, this work could not be completed due to the need for conservation work on the contact prints (mentioned in 3.2). All of the remaining, un-rehoused prints were placed back in their original file folders in the bankers boxes. These prints, (alphabetically $\mathrm{M}-\mathrm{Z}$ ) have been numbered, and all of the information associated with them has been transferred from the envelopes to the spreadsheet. With this understanding, the next step in processing this collection is to rehouse the prints by physically removing them from their current storage in bankers boxes, removing them from the paper sleeves they are adhered to, and rehousing them using Mylar sleeves and drop-front archival boxes. In order to rehouse the prints, I recommend a collaborative plan between the Conservation Department and the Department of Photographs to safely remove the prints from the sleeves to which they are adhered. Following the removal, prints should be handled in the same manner as those processed in the first half of the alphabet (Subjects A-L removed by students in the early stages of processing). Handling the prints in a like manner will avoid confusion when they are eventually stored together.

My next recommendation is to catalog all objects (negatives and prints) within the museum's collection management system, The Museum System (TMS), using the information contained in the spreadsheet. During the cataloguing process, matches can continue to be made between the negatives, contact prints and the photographic reproductions appearing in the Library's collection of Vanity Fair magazines (listed in Appendix I). This information would best be kept and accessed in the catalogue records allowing access by staff and researchers to these objects. However, completing the index requires locating a complete run of Vanity Fair and Vogue between 1923 and 1937 (Steichen's fourteen-year career at Condé Nast). This would be most valuable at the cataloguing stage. This would be a valuable step towards understanding 
the evolution of his method, and his reputation as a photographer of the elite and famous. Additionally, The Edward Steichen Archive at MoMA has posted an online finding aid, which has the potential to assist in matching prints, specifically Subseries III.B., Vanity Fair tearsheets. ${ }^{79}$ A review of the tear sheets would need to be made in order to assess their full relevance to this project. All together, access to Vanity Fair and Vogue magazines between 1923 and 1937 allow for a more cohesive understanding of his work during his years at Condé Nast. Likewise, it would link collection objects held within Eastman House.

The portion of processing described at length in this thesis was an essential stage in the life of the celebrity negatives and contact prints in the 2002 Joanna Steichen donation to George Eastman House. As a result of this project, other essential steps in processing were identified. While I was able to complete a large amount of work, additional planning and evaluation for the care and future of collection materials is essential to successfully managing large object-based collections, and making them available to the researching public. Time constraints and labor (I was the only person working on this material) weighed heavily upon my decisions and also upon my results. This applied thesis is a successful example of collection processing that provided both preservation and access to materials. By approaching the institution and objects with respect and expanding upon the understanding of the objects, this project insured future oresearch possibilities and the existence of the material for generations to come.

\footnotetext{
${ }^{79}$ Celia Hartmann, Finding Aid for "The Edward Steichen Archive at the Museum of Modern Art Archives" (New York: MoMA, 2011). http://www.moma.org/learn/resources/archives/EAD/steichenb.html (accessed February-May 2013).
} 


\title{
Appendix A
}

\author{
Original Processing Instructions
}

\section{Steichen Portrait Negative Project}

\section{Materials:}

Excel spreadsheet (Steichen numbering scheme)

Box of Steichen negatives and contact prints in original folders

New drop-front archival boxes

New archival sleeves (Gaylord Bros. Item\# PB810 8.5 x 10.5 - LC Pocket AF Buffered)

New Mylar sleeves (Gaylord SKU\# 20174610 self locking photo sleeves 3 mil)

New support boards (University Products \#9-5531-5 Lib. Br. 100\% Rag Med/Wt P/C)

3H Pencil

Cotton Gloves

\section{Directions:}

1. Remove folder from box of original materials (grouped by portrait subject's name). Count number of negatives and number of contact prints and input these numbers in the Excel spreadsheet.

2. Record any additional information written on the folder in the Excel spreadsheet (shoot date, publication name, etc.) ex: >>Apr. 30, 1925 Vogue.

3. With $3 \mathrm{H}$ pencil, write accession number (according to the Excel spreadsheet) of each negative on new archival sleeves - one sleeve per negative. Put the accession number at the top of the left edge of the sleeve, and write the subject's name on the bottom left edge of the sleeve.

4. Inspect each negative carefully for edge printing to see if material is nitrate. If Nitrate is written on the edge, record in Excel spreadsheet, put in sleeve and place in separate box of Nitrate negatives only (also refer to film notch code identification sheet).

5. Record the edge code of the negatives in the Excel spreadsheet.

6. Place negative in new paper sleeve, with notch code at top of sleeve, and emulsion side facing away from sleeve seam.

7. Carefully peel back original folder from contact print, being careful not to damage the print. Carefully remove any excess adhesive from the print.

8. With $3 \mathrm{H}$ pencil, write accession number (according to the Excel spreadsheet) on the lower left bottom edge of back of print. Place the print in new Mylar sleeve, with sleeve flap touching the back of print.

9. With $3 \mathrm{H}$ pencil, write accession numbers (according to the Excel spreadsheet) of the contact prints on new archival sleeve - maximum 8 prints per paper sleeve (if there is just one contact print for this subject, place a support board in Mylar sleeve with the print). Put the subject's name at the top of the left edge of the sleeve, and write the accession numbers on the bottom left edge of the sleeve.

10. Place the newly sleeved negatives in new drop-front box for negatives, and the newly sleeved prints in a different new drop-front box for prints. 
11. When each drop-front box is full of newly sleeved and labeled negatives or prints, write in pencil on the box: Steichen Portrait / Negatives (or Prints) / span of accession numbers included in box.

Example:

Steichen Portrait Negatives

L2001:3104:0001 - L2001:3171:0002

12. Save Excel spreadsheet often. 


\title{
Appendix B
}

\section{Modified Processing Instructions \\ Steichen Portrait Contact Prints and Negatives Step-by-Step Processing Instructions}

\author{
Materials: \\ -Excel spreadsheet (contains the Steichen numbering scheme) \\ -Bankers box of Steichen negatives and contact prints in original file folders \\ -New drop front archival boxes (Conservation Resources Item\#DF810MCS-Drop-front box, \\ $.060 \mathrm{MicroChamber/Silversafe)}$ \\ -New archival sleeves (Gaylord Bros. Item\# PB810 8.5 x 10.5-LC Pocket AF Buffered) for \\ negatives \\ -Clean support board (University Products \#9-5531-5 Lib. Br. 100\% Rag Med/Wt P/C) \\ $-3 \mathrm{H}$ Pencil \\ -Cotton Gloves
}

\section{Methodology:}

1. Remove file folder from bankers box of materials (roughly alphabetical by sitter's last name). Count the number of negatives and number of contact prints. Input these values into the Excel spreadsheet.

2. Record any additional handwritten information that appears on the file folder in the "Descriptions" field of the spreadsheet (shoot date, publication name, etc.).

$$
\text { Ex: "Apr. 30, } 1925 \text { V.F." }
$$

3. Write the accession number (assigned within the spreadsheet) of each negative on a new archival sleeve - one sleeve per negative. Position the folder horizontally, with the opening to the right. With $3 \mathrm{H}$ pencil, write the accession number on the top right edge of the sleeve, write the subject's name on the top left edge of the sleeve, first name, last name, and date by year (if available) to follow original method.

4. Record the notch code of the negatives in the appropriate spreadsheet field. If the negative is nitrate, additionally record "NITRATE" in the spreadsheet and "NITRATE" on the folder below the accession number.

5. Place the negative in a new paper sleeve, with the notch code at the top of sleeve, and the emulsion side facing away from sleeve seam (up).

6. Do not remove the print from the envelope to which it is adhered.

7. With $3 \mathrm{H}$ pencil, write accession number (listed in spreadsheet) on the lower left verso edge of the print.

8. Place the newly sleeved negative in a drop-front box designated for negatives. Return the contact print(s) to the original file folder and bankers box from which removed, being careful to keep the file folder in the same order it was removed from the bankers box.

9. When each drop-front box is full of newly sleeved and labeled negatives, write in pencil on the short side of the box (readable side when shelved): "Steichen Portrait Negatives" / span of accession numbers/ first and last sitter by last name. 
Example:

Steichen Portrait Negatives

2001:3262:0001 - 2001:3312:0002

Lady Diana Manners - Ethel Merman

10. Save Excel spreadsheet often.

11. Separate the Nitrate negatives from the full box (or placed in a nitrate-only box during processing). Once removed, title the box:

Steichen Portrait Negatives

NITRATE

Once full, set aside for transport to cold storage.

12. Within the box, place a box list. Keep a master box list. 


\section{Appendix C}

\section{Sample from "Negatives Box Inventory" 80 \\ Steichen Portrait Negatives \\ Box Inventory}

Box 2001:3262:0001 - 2001:3312:0002

60 total objects

Lady Diana Manners - Ethel Merman

Box 2001:3314:0001 - 2001:3324:0037

69 total objects

Ethel Merman and William Gaxton - Meyer Family Children

Box 2001:3326:0001 - 2001:3326:0056

56 total objects

Eugene Meyer - Eugene Meyer

Box 2001:3328:0001 - 2001:3330:0033

71 total objects

Meyer Family - Meyer Family Children

Box 2001:3332:0001 - 2001:3374:0001

83 total objects

Gilbert Miller - Princess Murat

Box 2001:3376:0001 - 2001:3408:0026

85 total objects

Mary Nash - Eugene O’Neill

Box 2001:3410:0001 - 001:3463:0022

77 total objects

Mr. Otto - Aileen Pringle

${ }^{80}$ For a complete box inventory, see Department of Photographs at George Eastman House. 


\section{Appendix D}

Sample Box List ${ }^{81}$

\section{Steichen Portrait Negatives}

\section{1:3262:0001 - 2001:3312:0002 Lady Diana Manners - Ethel Merman}

2001:3262:0001-Lady Diana Manners 2001:3262:0002-Lady Diana Manners 2001:3266:0001-Lady Diana Manners 2001:3266:0002-Lady Diana Manners 2001:3266:0003-Lady Diana Manners 2001:3268:0001-Carl Marr 2001:3272:0001-Herbert Marshall and Edna Best 2001:3272:0002-Herbert Marshall and Edna Best 2001:3274:0001-Mrs E Marshall Field 2001:3274:0002-Mrs E Marshall Field 2001:3276:0001-Mary and her mother 2001:3276:0002-Mary and her mother 2001:3278:0001-Mr and Mrs Massey (Raymond and Ilona) 2001:3278:0002-Mr and Mrs Massey (Raymond and Ilona) 2001:3280:0001-Princess Matchabelli 2001:3282:0001-Henri Matisse 2001:3282:0002-Henri Matisse 2001:3282:0003-Henri Matisse 2001:3282:0004-Henri Matisse 2001:3284:0001-The Matriarch 2001:3284:0002-The Matriarch 2001:3284:0003-The Matriarch 2001:3286:0001-Elsa Maxwell 2001:3286:0002-Elsa Maxwell 2001:3286:0003-Elsa Maxwell 2001:3286:0004-Elsa Maxwell 2001:3290:0001-Dr. E.V. McCullum 2001:3294:0001-Aline McMahon 2001:3294:0002-Aline McMahon 2001:3296:0001-Mei-Lan-Fang 2001:3296:0002-Mei-Lan-Fang 2001:3296:0003-Mei-Lan-Fang 2001:3298:0001-Adolphe Menjou 2001:3300:0001-Adolphe Menjou 2001:3302:0001-Helen Menken 2001:3304:0001-Helen Menken

\footnotetext{
${ }^{81}$ For complete box lists, see Department of Photographs at George Eastman House.
} 
2001:3304:0002-Helen Menken 2001:3306:0001-H.L. Menken 2001:3306:0002-H.L. Menken 2001:3306:0003-H.L. Menken 2001:3306:0004-H.L. Menken 2001:3306:0005-H.L. Menken 2001:3306:0006-H.L. Menken 2001:3306:0007-H.L. Menken 2001:3306:0008-H.L. Menken 2001:3306:0009-H.L. Menken 2001:3306:0010-H.L. Menken 2001:3306:0011-H.L. Menken 2001:3306:0012-H.L. Menken 2001:3306:0013-H.L. Menken 2001:3306:0014-H.L. Menken 2001:3306:0015-H.L. Menken 2001:3306:0016-H.L. Menken 2001:3306:0017-H.L. Menken 2001:3306:0018-H.L. Menken 2001:3308:0001-Beryl Mercer 2001:3310:0001-Philip Merivale 2001:3310:0002-Philip Merivale 2001:3312:0001-Ethel Merman 2001:3312:0002-Ethel Merman

Nitrate negatives removed from this box: 2001:3264:0001-Lady Diana Manners 2001:3264:0002-Lady Diana Manners 2001:3264:0003-Lady Diana Manners 2001:3264:0004-Lady Diana Manners 2001:3264:0005-Lady Diana Manners 2001:3270:0001-Marion Marsh 2001:3270:0002-Marion Marsh 2001:3288:0001-June McCloy 2001:3292:0001-Kenneth McKenna 2001:3300:0002-Adolphe Menjou 2001:3300:0003-Adolphe Menjou 


\section{Appendix E}

\section{Sample Box Labels ${ }^{82}$}

Steichen Portrait Negatives

2001:3262:0001 - 2001:3312:0002

Lady Diana Manners - Ethel Merman

Steichen Portrait Negatives

2001:3326:0001 - 2001:3326:0056

Eugene Meyer - Eugene Meyer

Steichen Portrait Negatives

2001:3332:0001 - 2001:3374:0001

Gilbert Miller - Princess Murat

Steichen Portrait Negatives

2001:3410:0001 - 2001:3463:0022

Mr. Otto - Aileen Pringle

Steichen Portrait Negatives

2001:3489:0043 - 2001:3536:0003

Carl Sandburg - Otis Skinner
Steichen Portrait Negatives

2001:3314:0001 - 2001:3324:0037

Ethel Merman and William Gaxton - Meyer Family Children

Steichen Portrait Negatives

2001:3328:0001 - 2001:3330:0033

Meyer Family - Meyer Family Children

Steichen Portrait Negatives

2001:3376:0001 - 2001:3408:0026

Mary Nash - Eugene O'Neill

Steichen Portrait Negatives

2001:3465:0001 - 2001:3489:0042

Sergei Rachmaninoff - Carl Sandburg

Steichen Portrait Negatives

2001:3538:0001 - 2001:3572:0002

Carmel Snow - Stieglitz and Kitty

\footnotetext{
${ }^{82}$ For complete box labels, see Department of Photographs at George Eastman House.
} 


\title{
Appendix F
}

\author{
Sample "Nitrate Box" List ${ }^{83}$ \\ Steichen Portrait Negatives
}

NITRATE

\section{(Includes 4 deteriorating acetate negatives)}

2001:3264:0001-Lady Diana Manners 2001:3264:0002-Lady Diana Manners 2001:3264:0003-Lady Diana Manners 2001:3264:0004-Lady Diana Manners 2001:3264:0005-Lady Diana Manners 2001:3270:0001-Marion Marsh 2001:3270:0002-Marion Marsh 2001:3288:0001-June McCloy 2001:3292:0001-Kenneth McKenna 2001:3300:0002-Adolphe Menjou 2001:3300:0003-Adolphe Menjou 2001:3412:0001-Maureen O'Sullivan 2001:3430:0001-Eric Pedley 2001:3520:0001-Norma Shearer and Irving Thalberg 2001:3520:0002-Norma Shearer and Irving Thalberg 2001:3520:0003-Norma Shearer and Irving Thalberg 2001:3520:0004-Norma Shearer and Irving Thalberg 2001:3520:0005-Norma Shearer and Irving Thalberg 2001:3530:0001-Sylvia Sidney 2001:3530:0002-Sylvia Sidney 2001:3530:0003-Sylvia Sidney 2001:3608:0001-Tashman Party-Joan Crawford and Douglas Fairbanks Jr. 2001:3608:0002-Tashman Party-Juliette Crosby and Arthur Hornblow 2001:3608:0003-Tashman Party-Kay Francis McKenna \& Kenneth McKenna 2001:3608:0004-Tashman Party 2001:3608:0005-Tashman Party 2001:3732:0001-Loretta Young 2001:3732:0002-Loretta Young 2001:3552:0009-Edward Steichen-Acetate negative with channeling 2001:3552:0010-Edward Steichen-Acetate channeling 2001:3552:0009-Edward Steichen-Acetate channeling

\footnotetext{
${ }^{83}$ For complete list, see Department of Photographs at George Eastman House.
} 


\title{
Appendix G
}

Sample from "Nitrate Materials Removed" List ${ }^{84}$

\section{Steichen Portrait Negatives}

Nitrate Materials Removed

\author{
Box 2001:3262:0001 - 2001:3312:0002 \\ 11 removed \\ 2001:3264:0001-Lady Diana Manners \\ 2001:3264:0002-Lady Diana Manners \\ 2001:3264:0003-Lady Diana Manners \\ 2001:3264:0004-Lady Diana Manners \\ 2001:3264:0005-Lady Diana Manners \\ 2001:3270:0001-Marion Marsh \\ 2001:3270:0002-Marion Marsh \\ 2001:3288:0001-June McCloy \\ 2001:3292:0001-Kenneth McKenna \\ 2001:3300:0002-Adolphe Menjou \\ 2001:3300:0003-Adolphe Menjou
}

Box 2001:3314:0001 - 2001:3324:0037

0 Removed

Box 2001:3326:0001 - 2001:3326:0056

0 Removed

Box 2001:3328:0001 - 2001:3330:0033

0 removed

Box 2001:3332:0001 - 2001:3374:0001

0 Removed

Box 2001:3376:0001 - 2001:3408:0026

0 removed

Box 2001:3410:0001 - 2001:3463:0022

2 removed

2001:3412:0001-Maureen O’Sullivan 2001:3430:0001-Eric Pedley

\footnotetext{
${ }^{84}$ For complete list, see Department of Photographs at George Eastman House.
} 


\section{Appendix H}

Table 5: Sample from Working Spreadsheet ${ }^{85}$

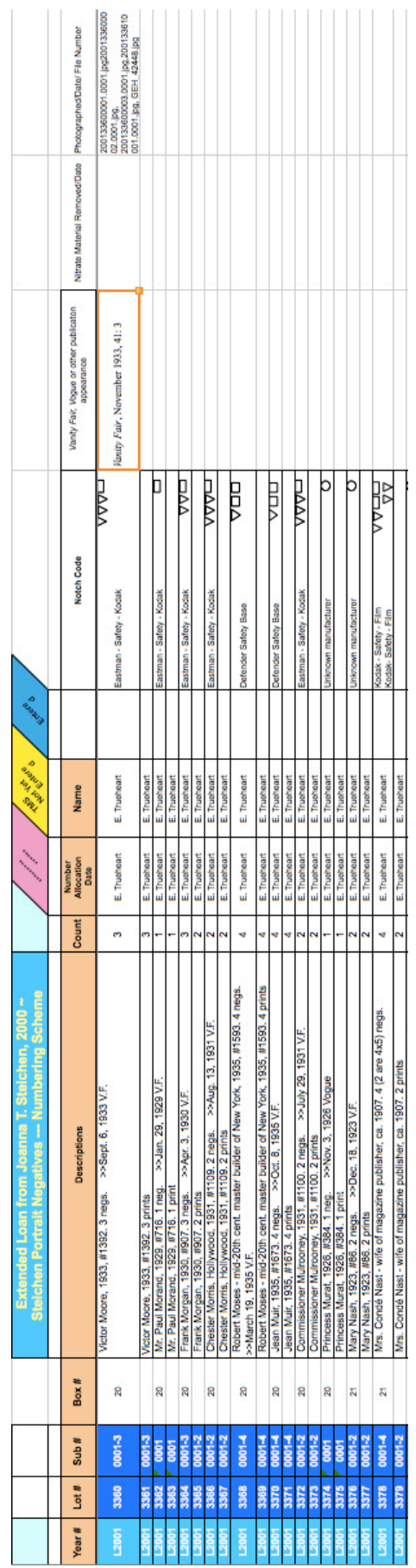

\footnotetext{
${ }^{85}$ For the entire spreadsheet, see Department of Photographs at George Eastman House.
} 


\section{Appendix I}

\section{Vanity Fair index with Illustrations ${ }^{86}$}

This appendix lists Eastman House Library holdings of Vanity Fair magazine within which Edward Steichen receives image credits. Each of the thirteen issues of Vanity Fair found at the Richard and Ronay Menschel Library are chronologically listed below by issue date and page number, and are accompanied by the names of persons appearing in the portraits in that issue. Highlighted names indicate the presence of the negative and/or proof print within the Steichen celebrity portrait collection. Thumbnail images of collections objects follow the magazine page or magazine spread in which the corresponding image appears. This list reflects the images matched from the L-Z lots, and is not a reflection of the materials processed prior to this thesis project $(\mathrm{A}-\mathrm{L})$.

Vanity Fair, April 1933, 40:2

- Pg 24 George Cohan

- Pg 28 Harold Nicholson

- Pg 29 Sir Arthur Salter

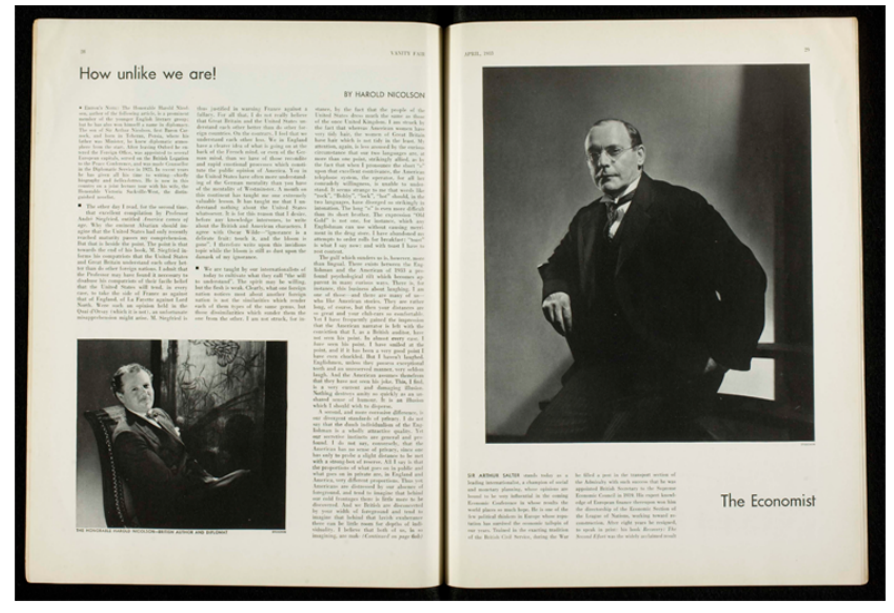

Figure 14

Vanity Fair, April 1933, Page 28, 29

Richard and Ronay Menschel Library

George Eastman House Collection

\footnotetext{
${ }^{86}$ Also includes an advertisement found in a publication entitled, The Delineator. Please see end of index.
} 

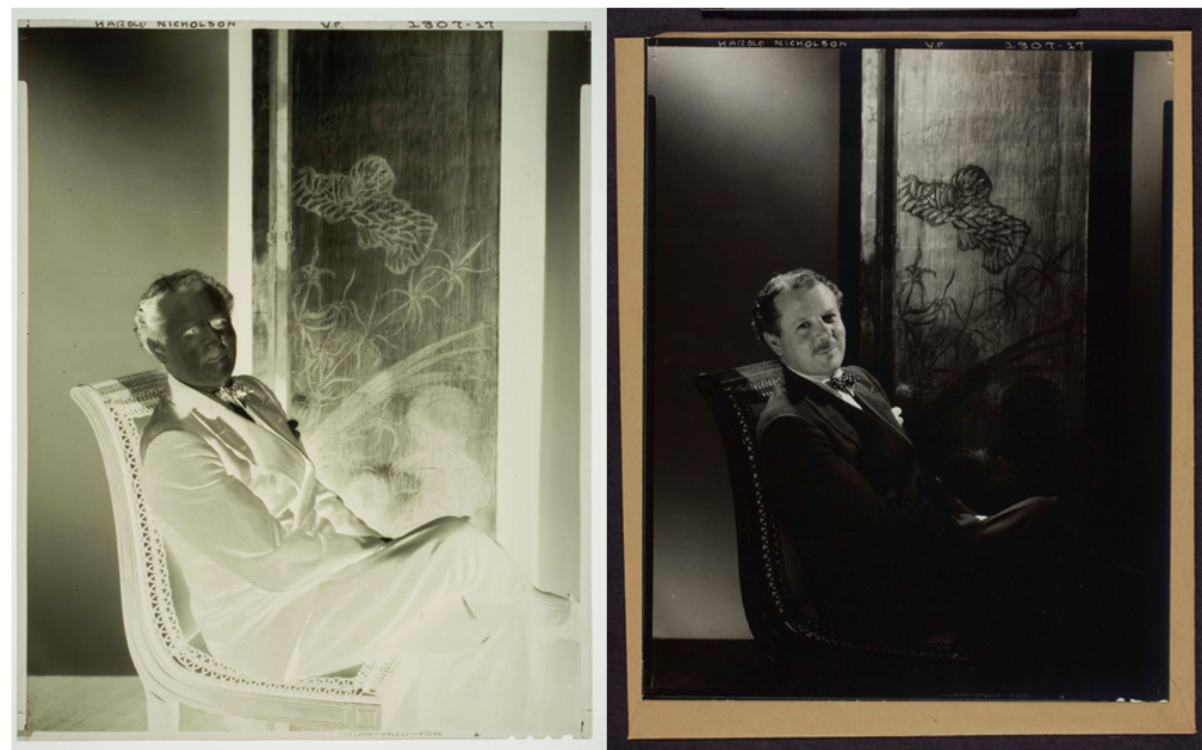

Figure 15

Edward Steichen

Harold Nicholson, January 6, 1933

Negative and contact print 2001:3388:0001

2001:3389:0001
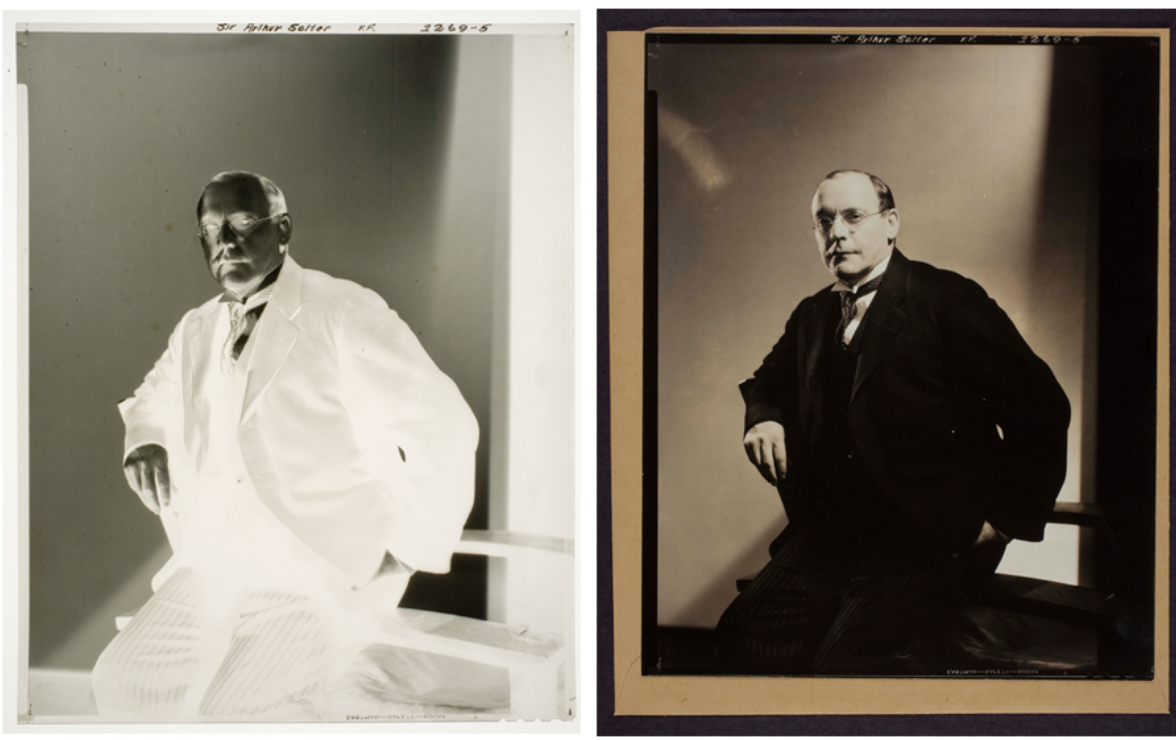

Figure 16

Edward Steichen Sir Arthur Salter, November 16, 1932 Negative and contact print 2001:3492:0004 2001:3393:0004 
Vanity Fair, July 1933, 40:5

- pg 23 Ruth Bryan Owen

- pg 30 Lily Pons

- pg 36 Worlds Fair Mural

- pg 40 Loretta Young

- pg 44 Aline McMahon

- $\quad$ pg 45 Elissa Landi

Figure 17

Vanity Fair, July 1933, Page 23

Richard and Ronay Menschel Library

George Eastman House Collection
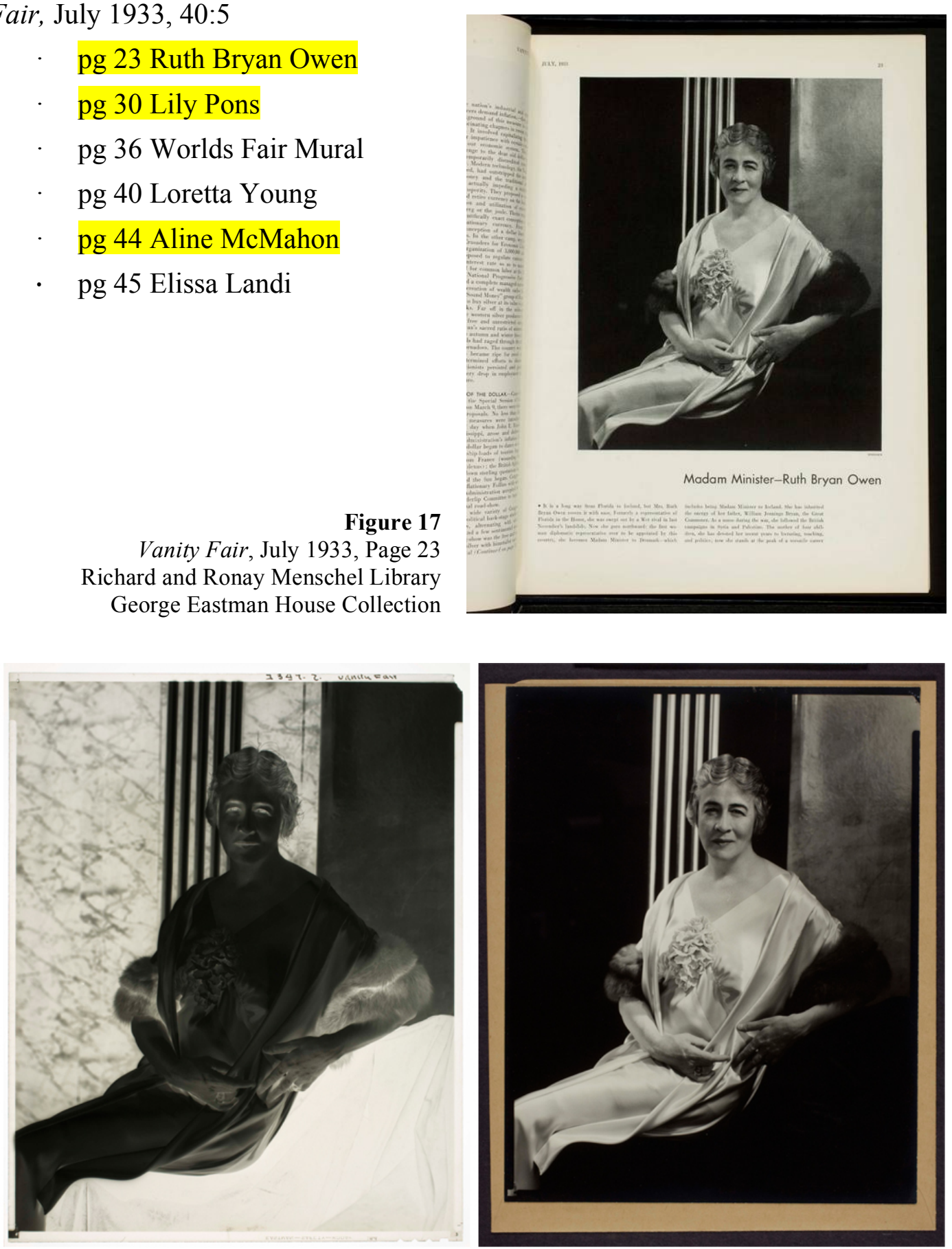

Figure 18

Edward Steichen Ruth Bryan Owen, May 8, 1933

Negative and contact print 2001:3414:0001 2001:3415:0001 
Figure 19

Vanity Fair, July 1933, Page 30

Richard and Ronay Menschel Library George Eastman House Collection
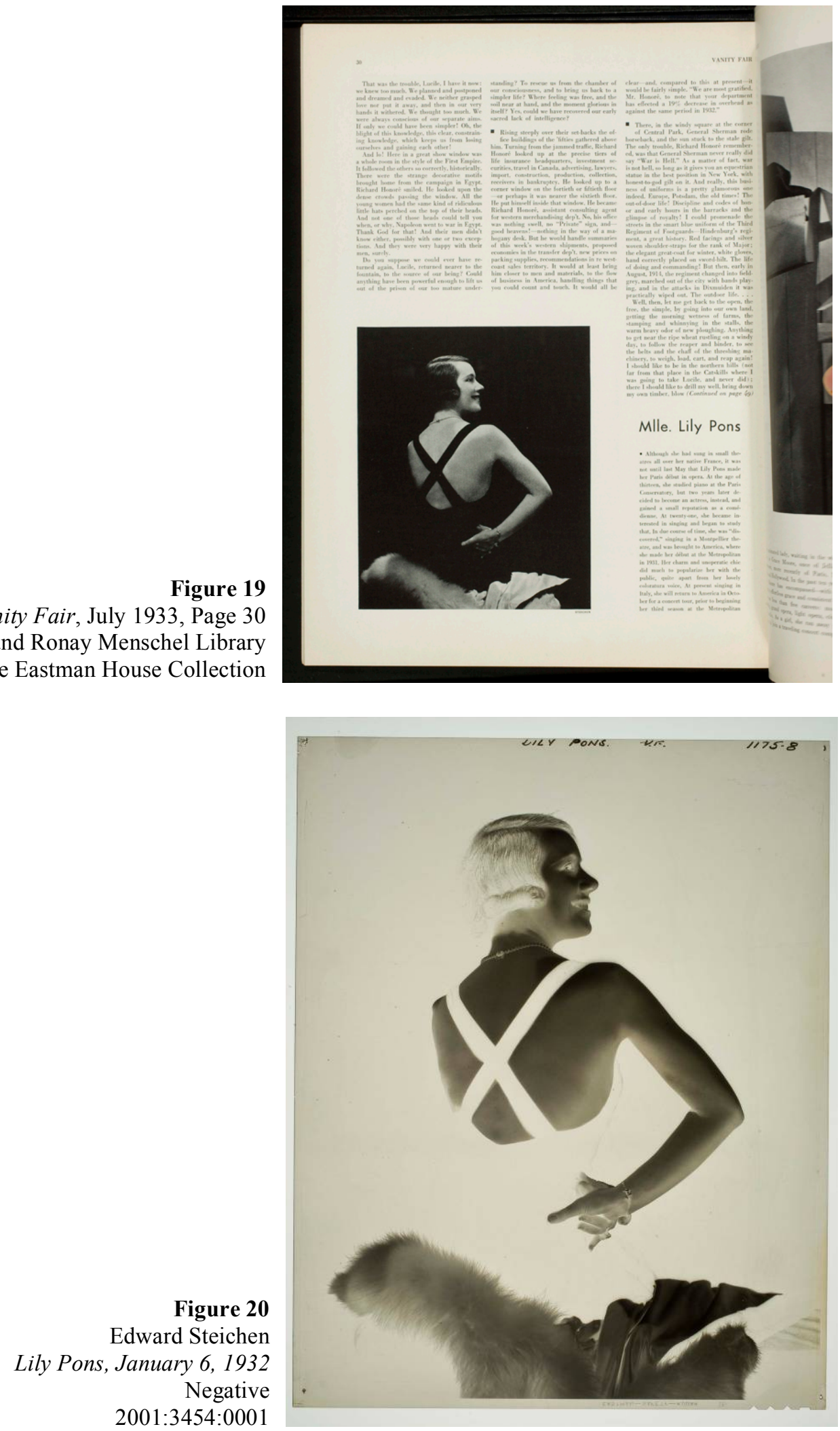

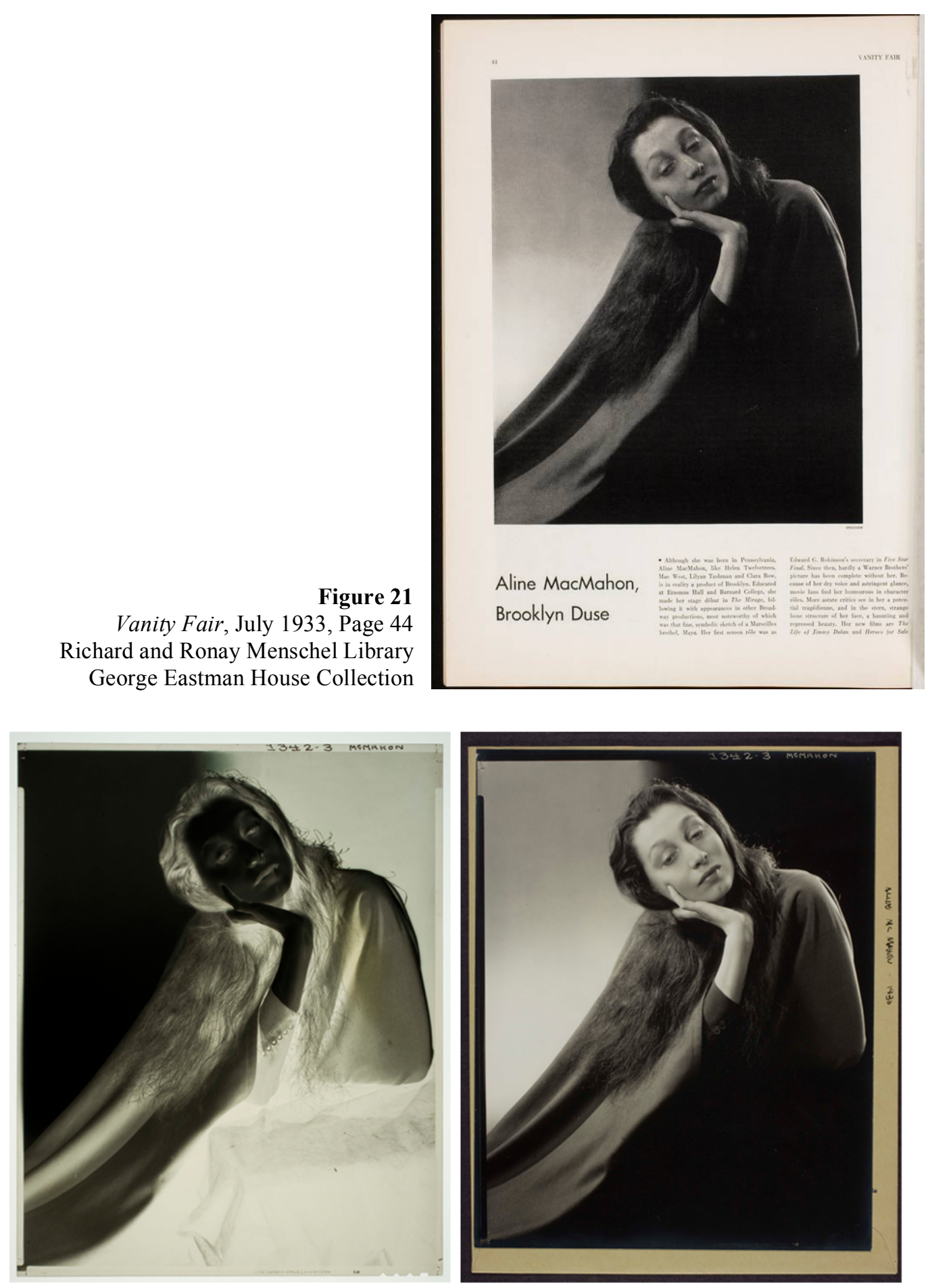

Figure 22

Edward Steichen Aline McMahon, 1933

Negative and contact print 2001:3294:0001 2001:3295:0001 
Vanity Fair, September 1933, 41:1

- pg 17 George Peek

- pg 30 Dorothy Jordan

- pg 40 Joe Cook

- pg 44 Rich Tauber
Figure 23

Vanity Fair, September 1933, Page 17 Richard and Ronay Menschel Library George Eastman House Collection
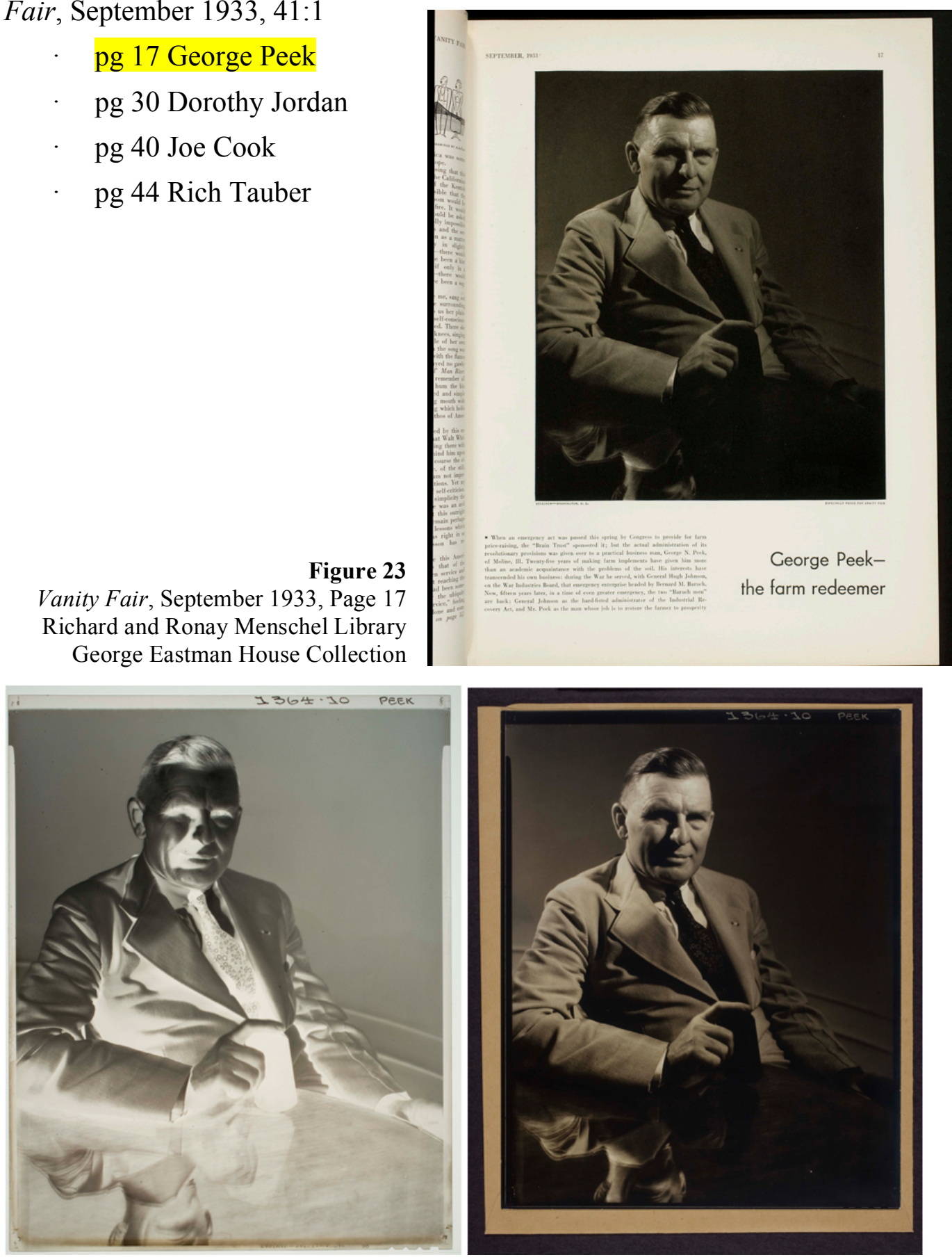

Figure 24

Edward Steichen

George Nelson Peek, May 27, 1933

Negative and contact print 2001:3432:0001

2001:3433:0001 
Vanity Fair, November 1933, 41: 3

- pg 19 Raymond Moley

- pg 42 Victor Moore

- pg 43 George M Cohan

- pg 46 Norma Shearer

- $\quad$ pg 47 Mary Astor

Figure 25

Vanity Fair, November 1933, Page 19

Richard and Ronay Menschel Library

George Eastman House Collection
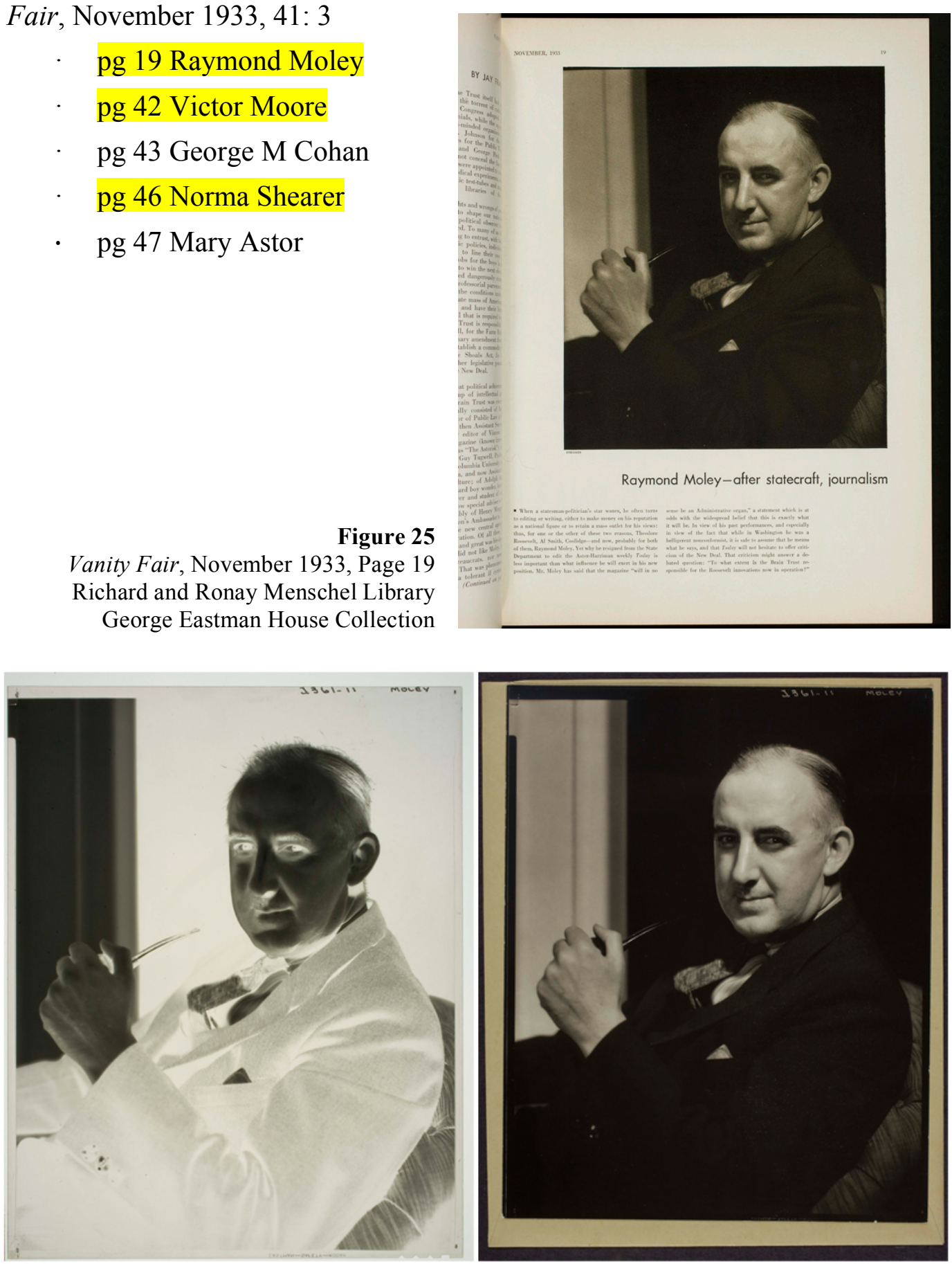

Figure 26

Edward Steichen Raymond Moley, May 24, 1933

Negative and contact print 2001:3340:0001 2001:3341:0001 

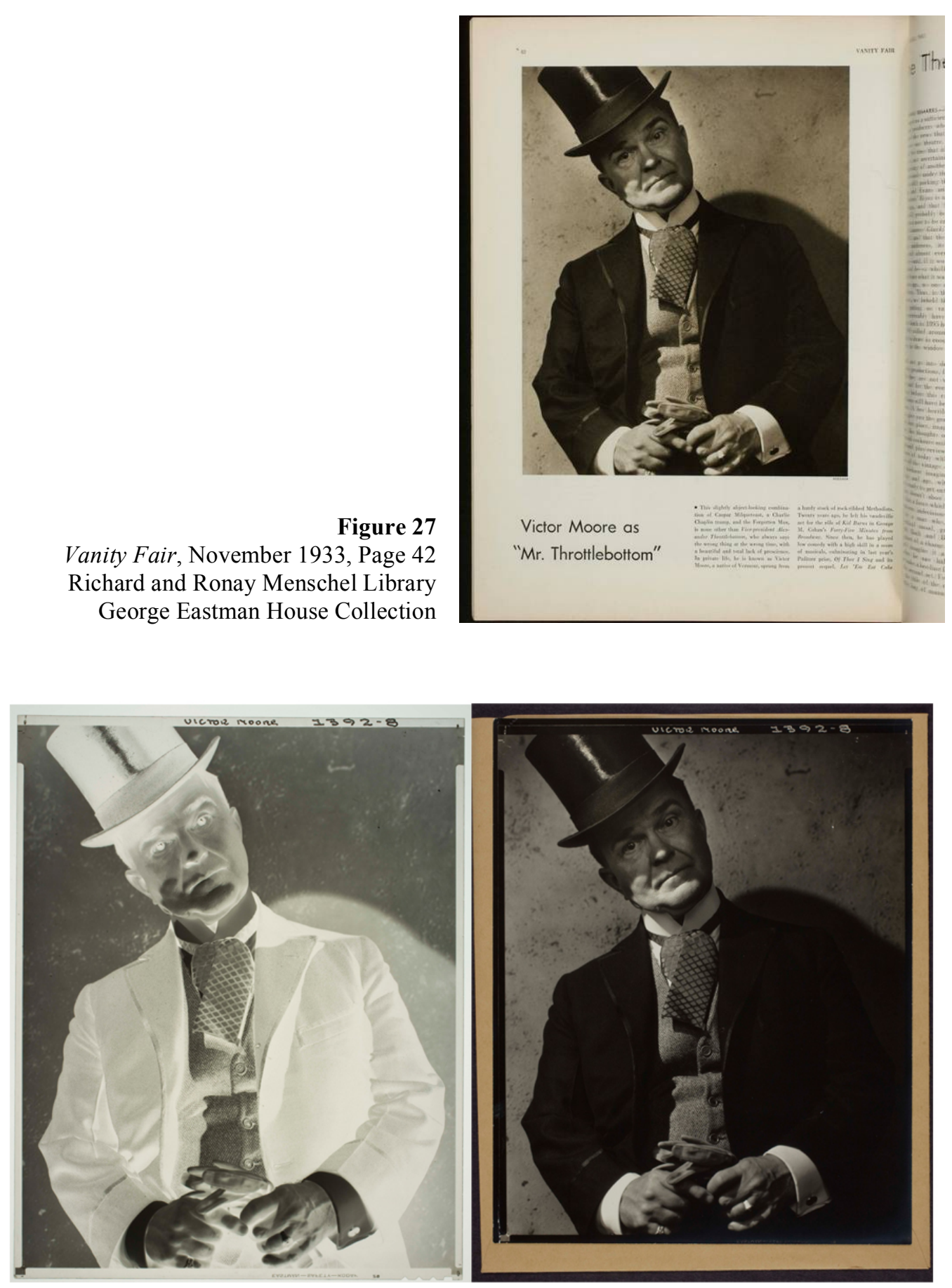

Vanity Fair, November 1933, Page 42 Richard and Ronay Menschel Library George Eastman House Collection

Figure 28

Edward Steichen

Victor Moore as Alexander Throttlebottom in “Of Thee I Sing," 1933

Negative and contact print 2001:3360:0001 2001:3361:0001 

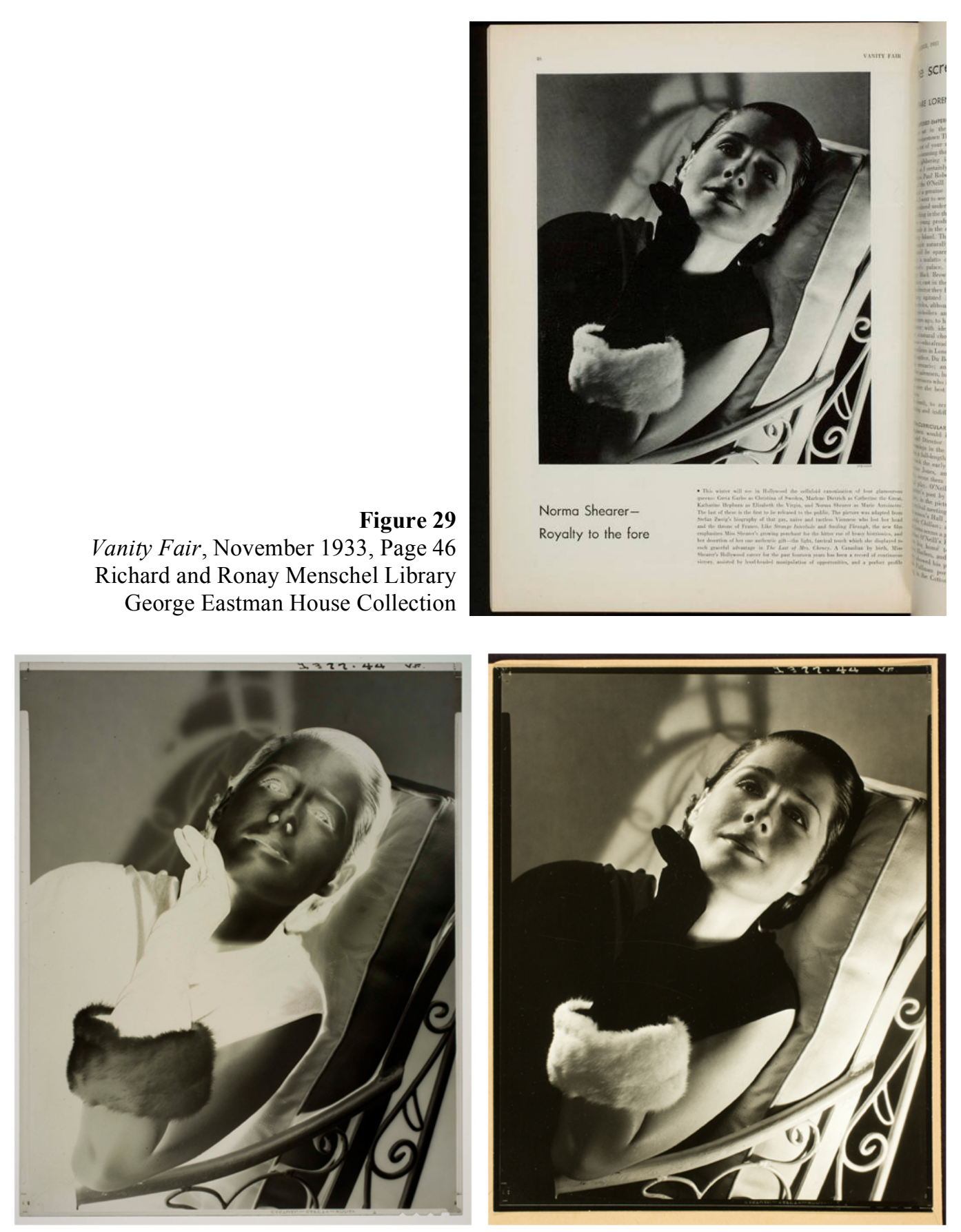

Figure 30

Edward Steichen Vanity Fair, November 1933, Page 46 Richard and Ronay Menschel Library George Eastman House Collection 
Vanity Fair, January 1934, 41:5

- pg 44 Leslie Howard

- pg 45 Kathryn Hepburn

- pg 47 Marie Dressler

Vanity Fair, April 1934, 42:2

- pg $35 \mathrm{Jim}$ Browning and Kurt Gabriel

- pg 38 "Masks for American Drama-12 Photographs by Steichen"-12 unidentified sitters

- pg 48 Dolores Del Rio

- pg 51 Madys Christian 
Vanity Fair, June 1934, 42:4

- $\quad$ pg 24 Cardell Hull

- pg 29 Garbo and Dietrich (photo composite)

- pg 32 WC Fields

- $\quad$ pg 43 Primo Carrera

- pg 47 Walter Duranty

- pg 52 Lupe Velez

- . pg 56 Leila Hyams

- . pg 60 Eleanor Holm

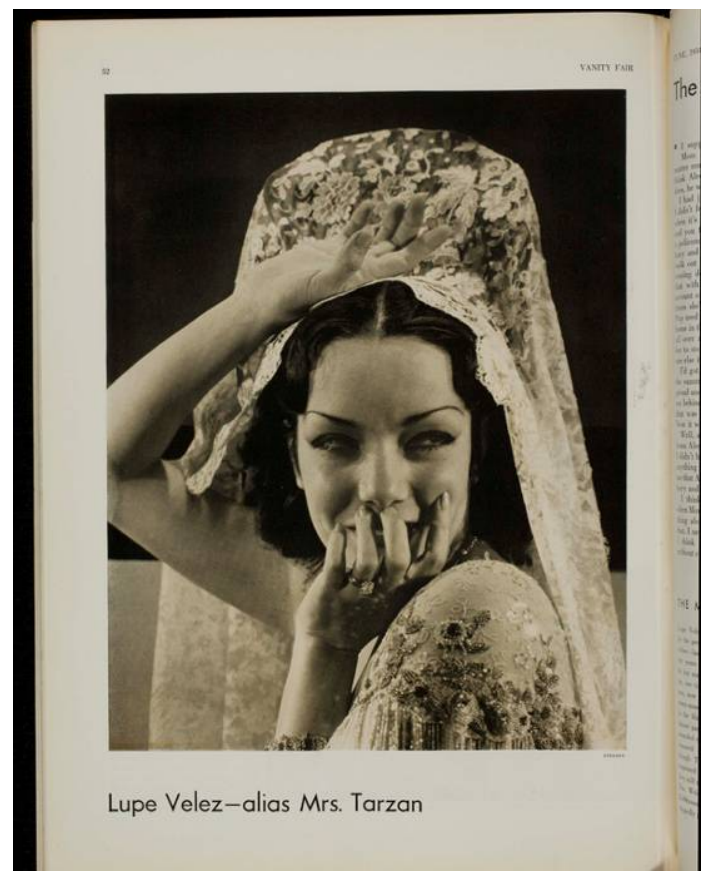

Figure 31

Vanity Fair, June 1934, Page 52

Richard and Ronay Menschel Library George Eastman House Collection
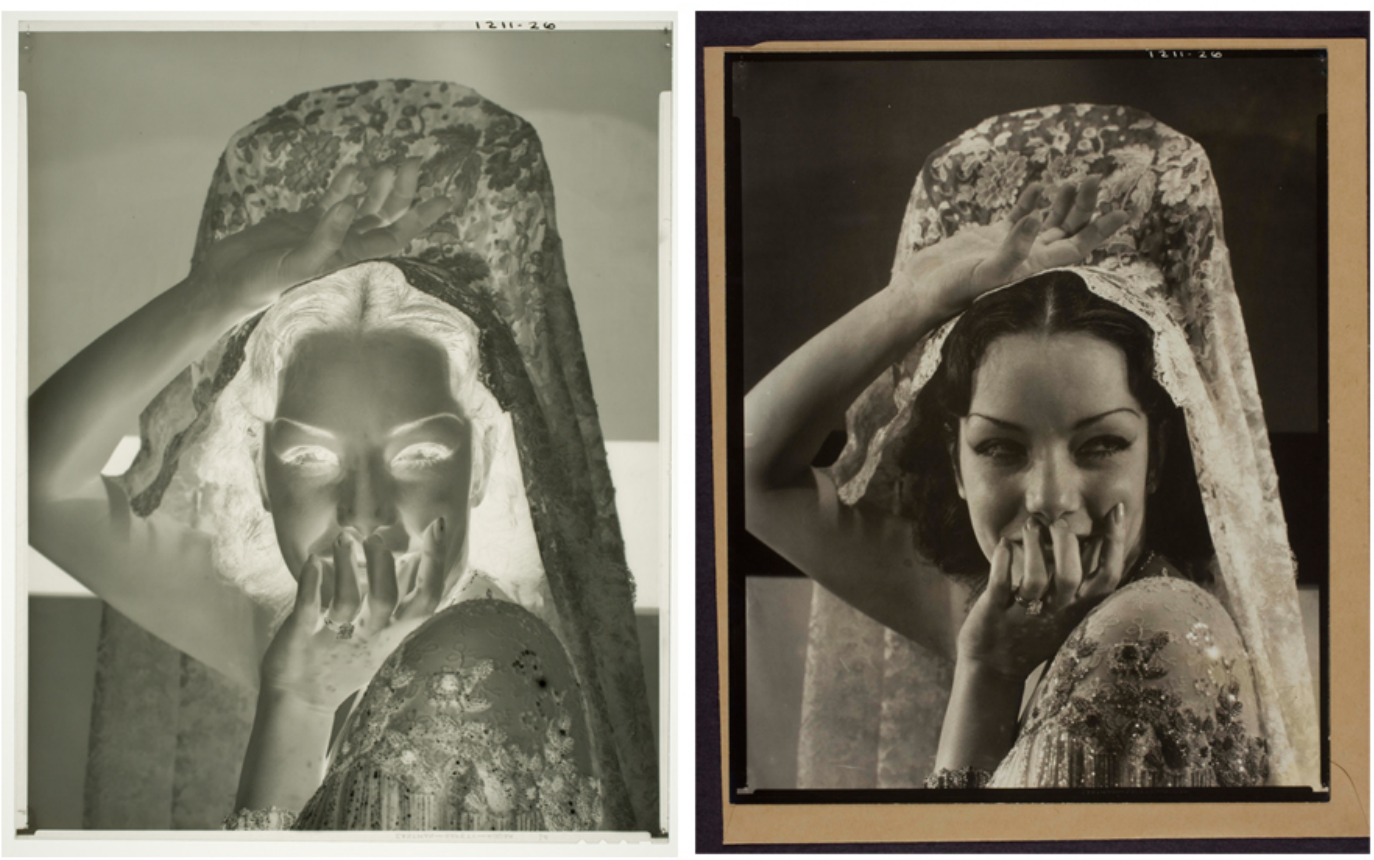

Figure 32

Edward Steichen

Lupe Velez, August 15, 1932

Negative and contact print 2001:3652:0003

2001:3653:0003 

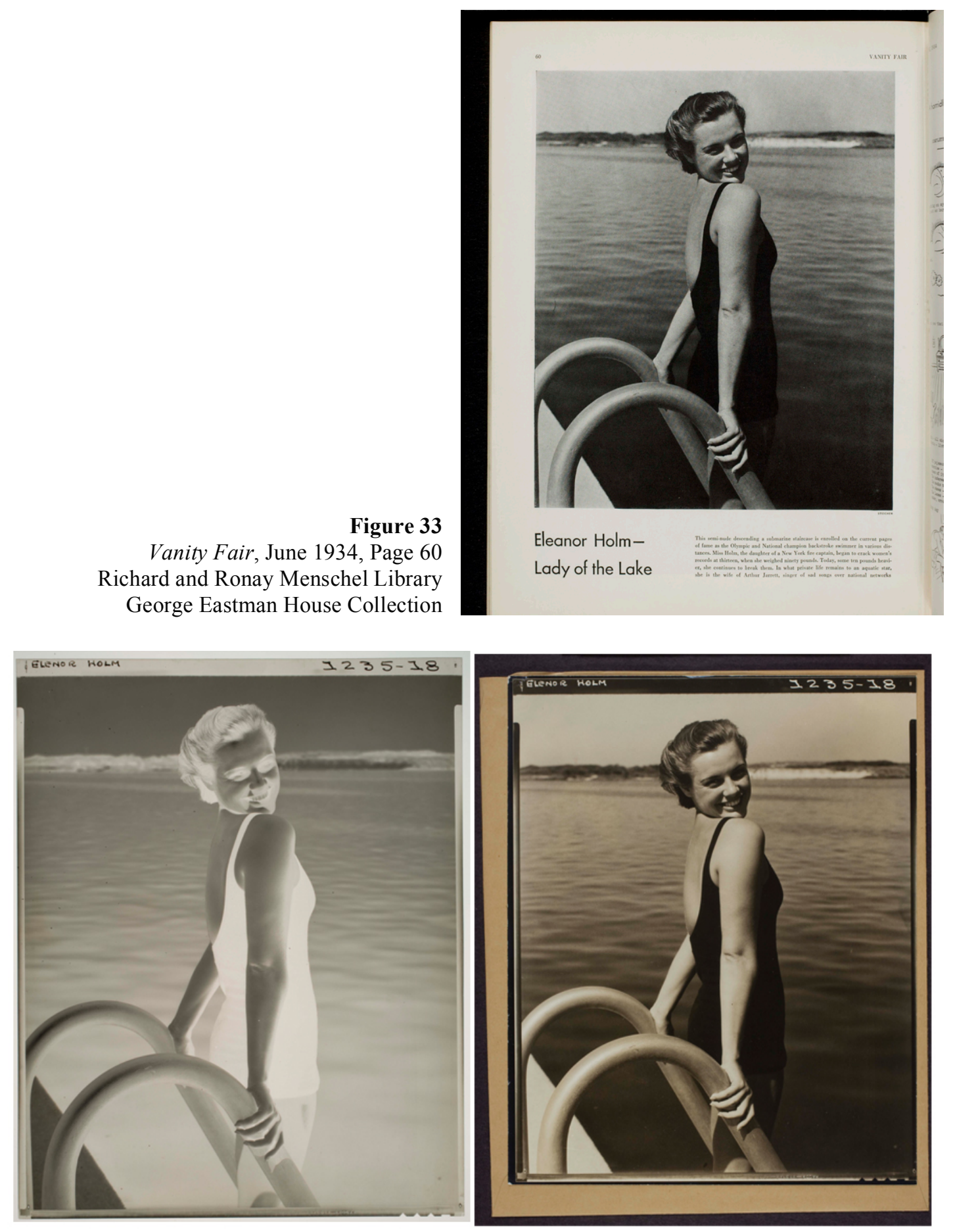

Figure 34

Edward Steichen

Eleanor Holm, July 14, 1932

Negative and contact print 2001:3396:0011

2001:3397:0011 
Vanity Fair, July 1934, 42:5

- pg 21 Annabella

Vanity Fair, August 1934, 42:6

- pg 20 Thomas Mann

- $\quad$ pg 52 Self portrait in "Photographers by photographers

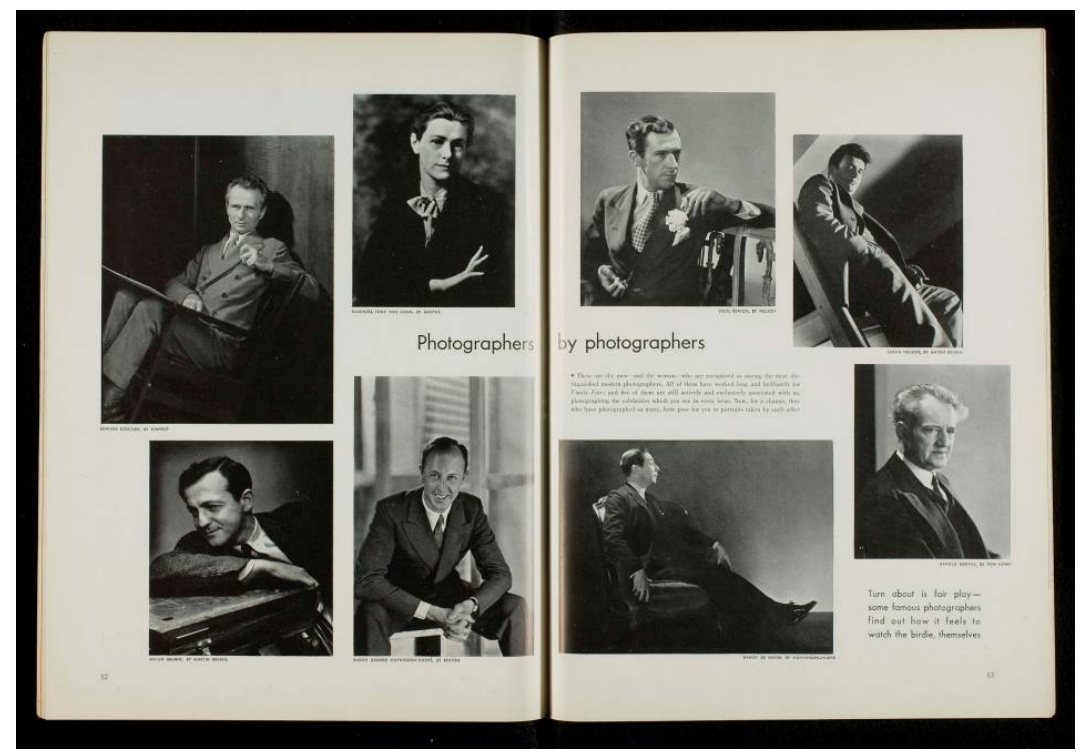

Figure 35

Vanity Fair, August 1934, Page 52, 53 Richard and Ronay Menschel Library George Eastman House Collection
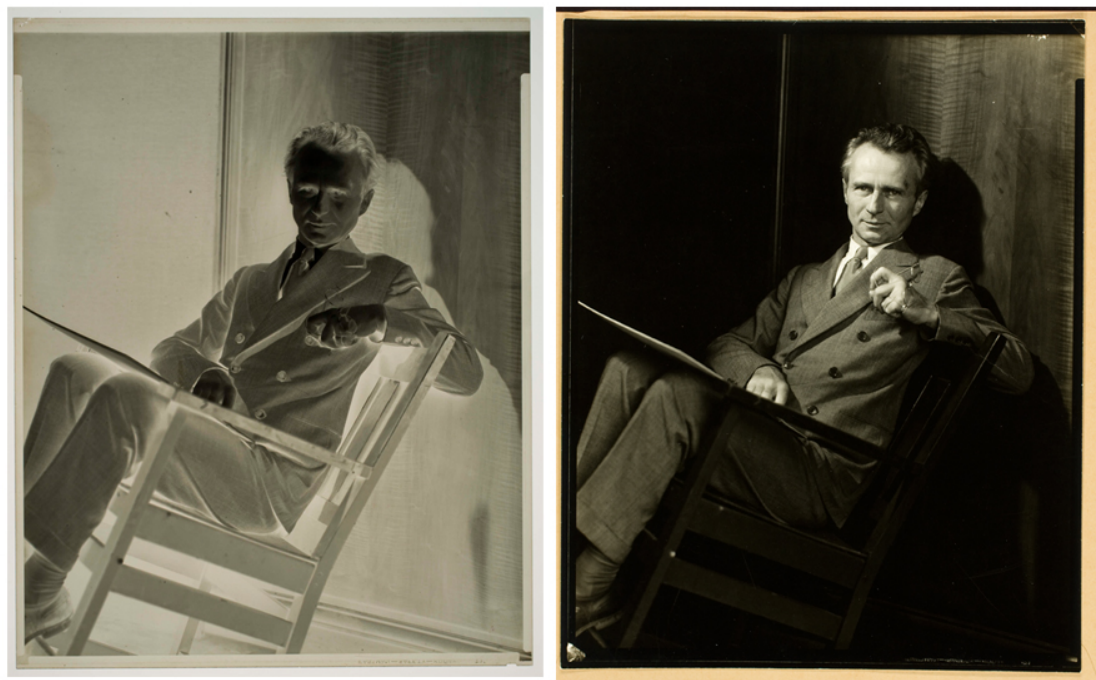

Figure 36

Edward Steichen, Self-Portrait

Negative and contact print 2001:3554:0016 2001:3555:0015 
Vanity Fair, February 1935, 43:6

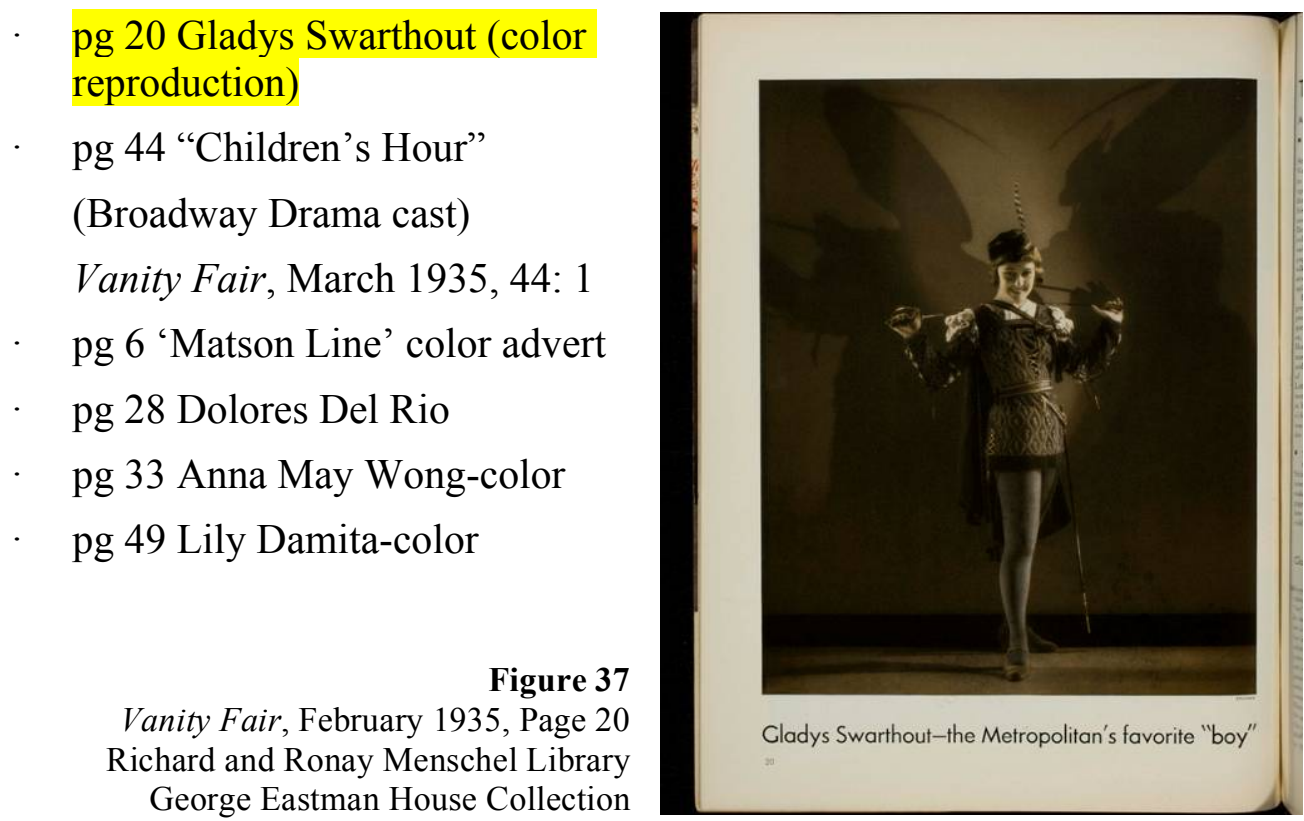

Figure 38

Edward Steichen,

Gladys Swarthout as Stephano

in "Romeo and Juliet" at the

Metropolitan Opera, 1934

Red filter negative and contact print 2001:3594:0001 2001:3595:0001
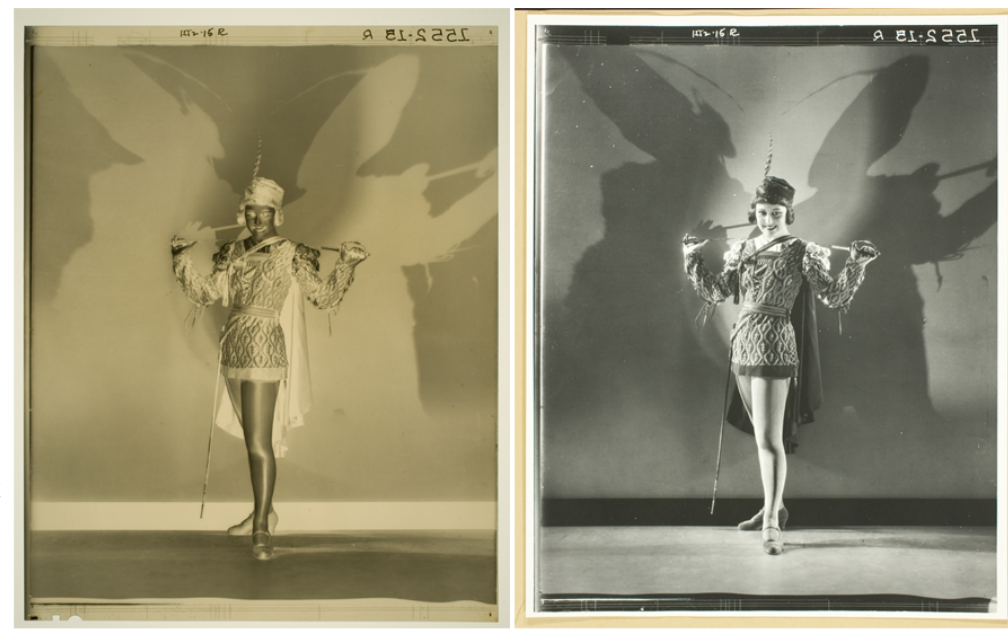

Figure 39

Edward Steichen

Gladys Swarthout as Stephano

in "Romeo and Juliet" at the Metropolitan Opera, 1934

Blue filter negative and contact print 2001:3594:0002 2001:3595:0002
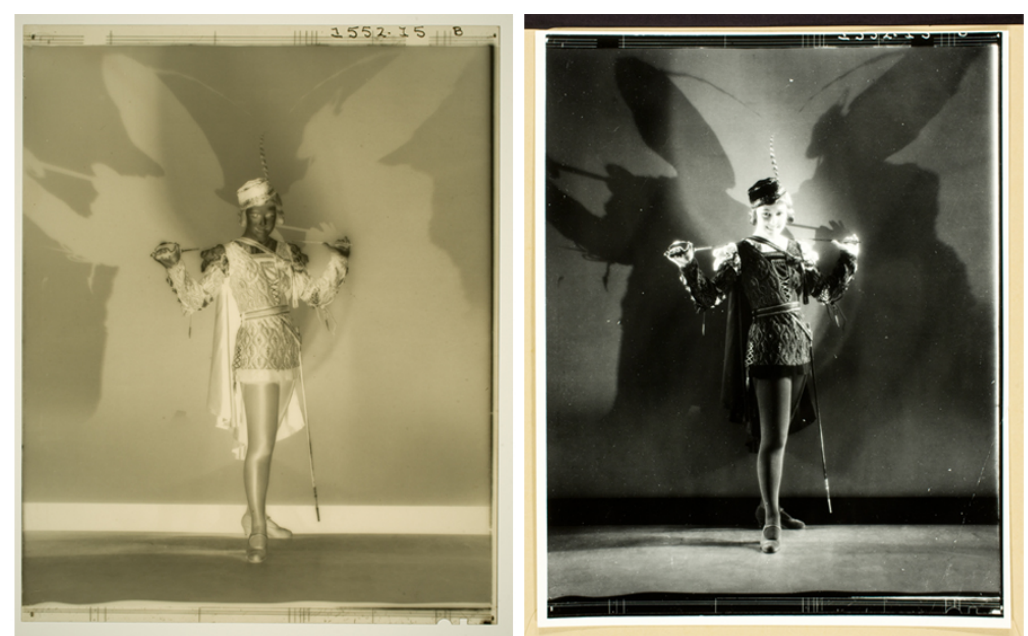
Vanity Fair, April 1935, 44:2

- pg 21 Philipe Merivale

- pg 22 Elisabeth Berger

- pg 23 Louis Hayward

- $\quad$ pg 24 Jane Cowl

- pg 39 Ballet snapshots in color
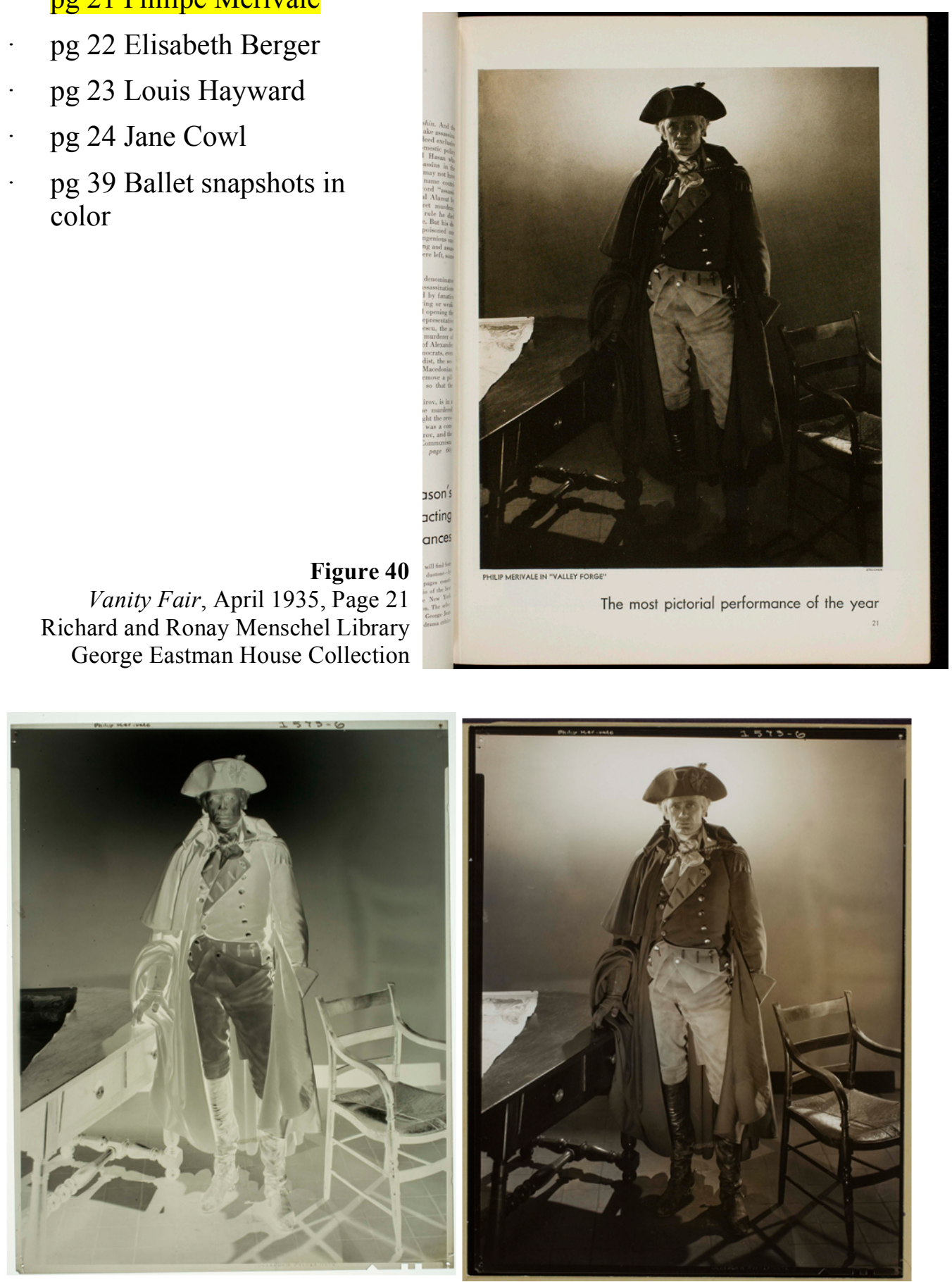

Vanity Fair, April 1935, Page 21

Richard and Ronay Menschel Library

George Eastman House Collection

Figure 41

Edward Steichen,

Philip Merivale as General George Washington in "Valley Forge," 1935

Negative and contact print

2001:3310:0001

2001:3311:0001 
Other Publications:

The Delineator, October 1931

- pg 33 Lady Milford Haven

- $\quad$ (Ponds Cold Cream ad)

Figure 42

The Delineator, October 1933, Page 23
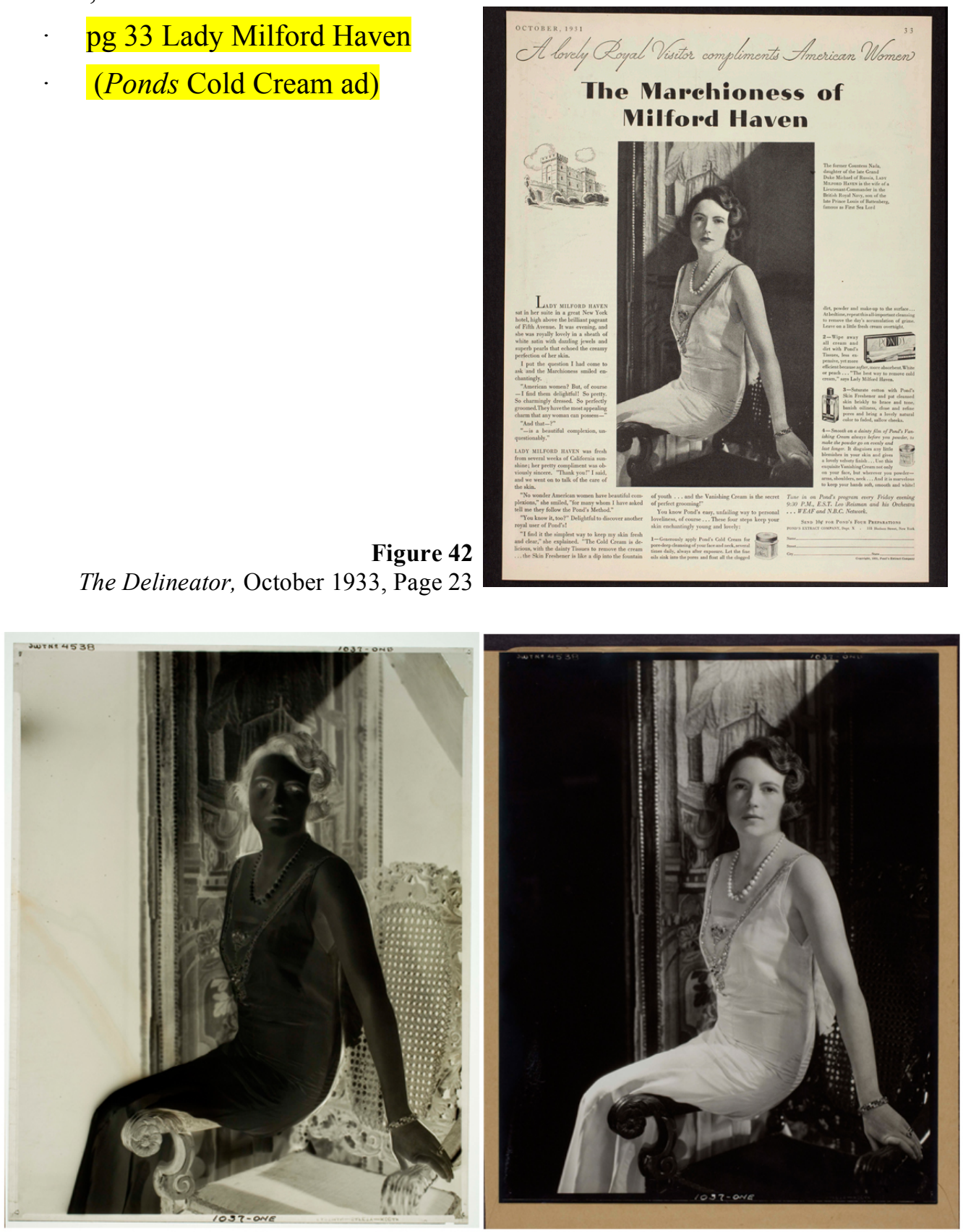

Figure 43

Edward Steichen Lady (Marchioness) Milford Haven, 1931 Negative and contact print 2001:3452:0002 2001:3453:0002 


\section{Bibliography}

\section{Edward Steichen:}

Booth Brokaw, Clare “Edward Steichen, Photographer,” Vanity Fair, June 1932.

Brandow, Todd and William A. Ewing. Edward Steichen: Lives in Photography.

Case-Harriman, Margaret. “Steichen,” Vogue, January 1938.

Ewing, William A. "In Perfect Conjunction." In Edward Steichen: In High Fashion, the Condé Nast Years, 1923-1937. Minneapolis: FEP Editions LLC in association with W.W. Norton \& Co., 2007.

—. "Preface and Acknowledgements: In High Fashion." In Edward Steichen: In High Fashion, the Condé Nast Years, 1923-1937. Minneapolis: FEP Editions LLC in association with W.W. Norton \& Co., 2007.

Haskell, Barbara. Edward Steichen. New York: Whitney Museum of Modern Art, 2000.

Herschdorfer, Nathalie. “Models and Sitters: A Who's Who.” In Edward Steichen: In High Fashion, the Conde Nast Years, 1923-1937. Minneapolis: FEP Editions LLC in association with W.W. Norton \& Co., 2007.

Mayer, Grace M. “Biographical Outline.” In Steichen the Photographer. New York: The Museum of Modern Art, 1961.

Niven, Penelope. Steichen: A Biography. New York: Clarkson Potter Publishers, 2004.

Steichen, Edward. A Life in Photography. London: W.H. Allen, 1963.

Steichen, Joanna. Steichen's Legacy: Photographs, 1895-1973. New York: Alfred A. Knopf, 2000 .

Squiers, Carol. "Edward Steichen at Condé Nast Publications." In Edward Steichen: In High Fashion, the Condé Nast Years, 1923-1937. Minneapolis: FEP Editions LLC in association with W.W. Norton \& Co., 2007.

Voguepedia. "Photographers: Edward Steichen." http://www.vogue.com/voguepedia/Edward_Steichen (Accessed February-May 2013). 


\section{Archival Management:}

Bertrand Lavédrine, Bertrand. Photographs of the Past: Process and Preservation. Los Angeles: The Getty Conservation Institute 2009.

The Library of Congress. "Care, Handling, and Storage of Photographs."

http://www.loc.gov/preservation/care/photo.html (accessed July 25, 2013).

Lutek, Tasha. "The Specimens Box: A Case Study in Cataloguing at George Eastman House." Master's thesis, Ryerson University, 2010. In Digital Commons at Ryerson University, $\mathrm{http}$ //digitalcommons.ryerson.ca/cgi/viewcontent.cgi?article $=2227 \&$ context $=$ dissertation s (Accessed July 25, 2013).

Pearce-Moses, Richard. A Glossary of Archival and Records Terminology. Archival Fundamentals Series II. Chicago: Society of American Archivists, 2005.

Ritzenthaler, Mary Lynn. Preserving Archives and Manuscripts. Chicago: Society of American Archivists, 1993.

Stuchell, Lance. "Creating Finding Aids at the Benson Ford Research Center." Dearborn, MI: Benson Ford Research Center, The Henry Ford, 2012.

\section{Film handling and identification:}

Calhoun, J.M. "Storage of Nitrate Amateur Still-Camera Film Negatives." In The Journal of the Biological Photographic Association. New York: JBPA, August 1953.

Fischer, Monique C. and Andrew Robb. "Guidelines for Care \& Identification of Film-Base Photographic Materials." In Topics in Photographic Preservation, Volume 5. Washington, DC: AIC, 1993.

Knapp, Anthony M. and Diane Vogt-O'Connor. "Caring for Cellulose Nitrate Film." Conserve $O$ Gram, 14/8. Washington, DC: National Park Service, 2010.

Kodak. "Kodak Environmental Services: Safe Handling, Storage, and Destruction of NitrateBased Motion Picture Films." KODAK Publication No. H-182. Rochester, NY: Eastman Kodak Company, 2003.

National Park Service. "Caring for Cellulose Nitrate Film.” Conserve O' Gram, August 2003. Washington, DC: National Park Service Museum Management Program, 2004.

_. "Handling and Shipping Cellulose Nitrate Film." Conserve O' Gram, June 2003. Washington, DC: National Park Service Museum Management Program, 2003.

—. "Identification of Film-Base Photographic Materials." Conserve O' Gram, September 1999. Washington, DC: National Park Service Museum Management Program, 1999. 
National Film Preservation Foundation. "6.5 Storing Nitrate Film.” In The Film Preservation Guide: The Basics for Archives, Libraries, and Museums. San Francisco, CA: The National Film Preservation Foundation, 2004. 65.

http://www.filmpreservation.org/userfiles/image/PDFs/fpg_6.pdf (Accessed July 31, 2013).

National Fire Protection Association. "Standard for the Storage and Handling of Cellulose Nitrate Film, NFPA 40.” Quincy, MA: National Fire Protection Association, 2001. http://www.nfpa.org (accessed July 25, 2013).

Northeast Document Conservation Center. "Preservation Leaflet 5.1-A Short Guide to Film Base Photographic Materials: Identification, Care and Duplication.” Andover, MD: Northeast Document Conservation Center, 2008.

Reilly, James M. IPI Storage Guide for Acetate Film. Rochester, NY: Image Permanence Institute, 1993. http://www.imagepermanenceinstitute.org/webfm_send/299.

Valverde, María Fernanda. Photographic Negatives: Nature and Evolution of Processes. Rochester, NY: Image Permanence Institute, 2005.

\section{Other sources:}

Dixon, Penelope. "Section V. Description of Work." In An Appraisal of Photographic Materials by Edward Steichen Provided for Joanna Steichen. Penelope Dixon \& Associates, Inc., October 15, 2000. Reprinted with permission from The Estate of Edward Steichen.

Hartmann, Celia. Finding Aid for "The Edward Steichen Archive at the Museum of Modern Art Archives." New York: The Museum of Modern Art, 2011. http://www.moma.org/learn/resources/archives/EAD/steichenb.html.

Internet Broadway Database. “Of Thee I Sing.” Accessed February-May 2013. The Broadway League Inc., 2013. http://www.ibdb.com/production.php?id=11468.

Steichen, Joanna. "Receipt, Release, Refunding and Indemnification Agreement (File No.2010-2660)." State of New York, New York County, Surrogate's Court, 2010. Reprinted with permission from The Estate of Edward Steichen.

Wikipedia. "Of Thee I Sing.” Accessed February-May 2013. http://en.wikipedia.org/wiki/Of_Thee_I_Sing. 